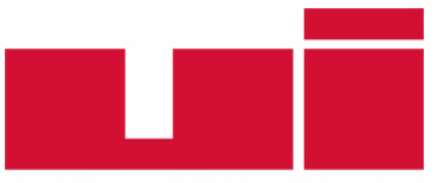

ULUUSLARARASTILIŞKiLER

Akademik Dergi

Yayın ilkeleri, izinler ve abonelik hakkında ayrıntılı bilgi:

E-mail: bilgi@uidergisi.com.tr

Web: www.uidergisi.com.tr

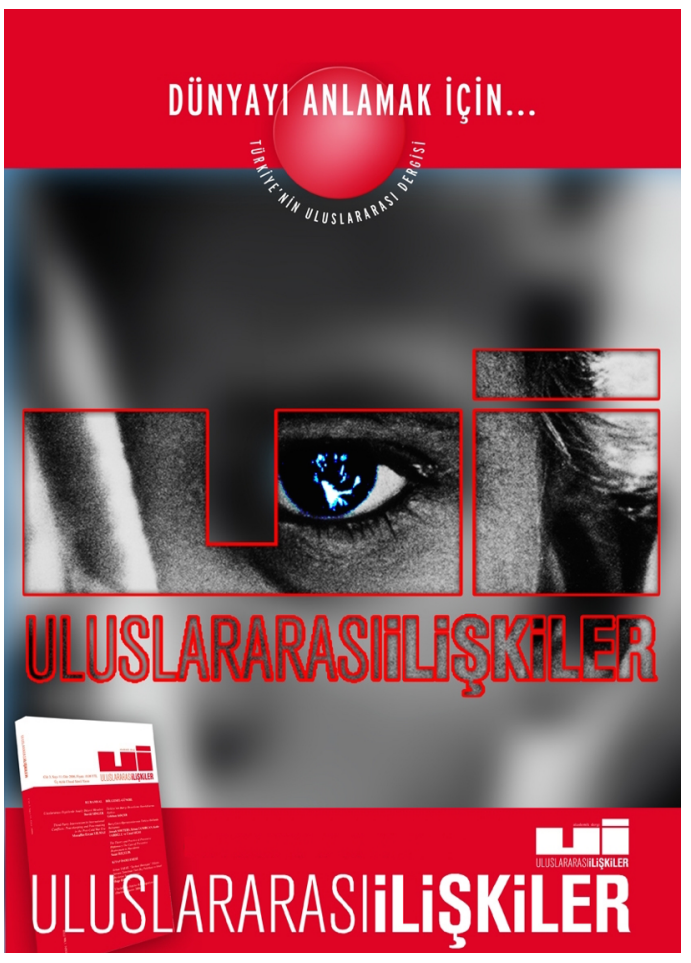

\title{
Kürdistan Bölgesel Yönetimi: Rantçı Devlet Yaklaşımı Çerçevesinde Bir Dĕgerlendirme
}

\section{Göktürk TÜYSÜZOĞLU*}

* Yrd. Doç. Dr., Giresun Üniversitesi, Uluslararası İlişkiler Bölümü

Bu makaleye atıf için: Tüysüzoğlu, Göktürk, "Kürdistan Bölgesel Yönetimi: Rantçı Devlet Yaklaşımı Çerçevesinde Bir Değerlendirme", Uluslararası Ilişskiler, Cilt 12, Say1 47, s. 73-98.

Bu makalenin tüm hakları Uluslararası İlişkiler Konseyi Derneği’ne aittir. Önceden yazılı izin alınmadan hiç bir iletişim, kopyalama ya da yayın sistemi kullanılarak yeniden yayımlanamaz, çoğaltılamaz, dağıtılamaz, satılamaz veya herhangi bir şekilde kamunun ücretli/ücretsiz kullanımına sunulamaz. Akademik ve haber amaçlı kısa alıntılar bu kuralın dışındadır.

Aksi belirtilmediği sürece Uluslararası Illişkiler'de yayınlanan yazılarda belirtilen fikirler yalnızca yazarına/yazarlarına aittir. UİK Derneğini, editörleri ve diğer yazarları bağlamaz.

Uluslararası İlişkiler Konseyi Derneği | Uluslararası İlişkiler Dergisi

Web: www.uidergisi.com.tr| E- Posta: bilgi@uidergisi.com.tr 


\title{
Kürdistan Bölgesel Yönetimi: Rantçı Devlet Yaklaşımı Çerçevesinde Bir Değerlendirme
}

\author{
Göktürk TÜYSÜZOĞLU \\ Yrd. Doç. Dr., Uluslararası İlişkiler Bölümü, İIBB, Giresun Üniversitesi, Giresun. \\ E-posta: gktrkt@gmail.com
}

\section{ÖZET}

Rantçı devlet yaklaşımı, bütün gelirini tek bir doğal kaynak üzerinden elde eden ülkeleri tanımlamaktadır. Bu ülkeler yapı itibarıyla otoriter bir görünüm sergiler ve siyasal/ekonomik işleyiş bakımından halk oldukça edilgen bir karaktere sahiptir. Rantçı devlet yaklaşımı çerçevesinde değerlendirdiğimizde, bağımsız bir devlet olmasa da, Kürdistan Bölgesel Yönetimi’nin de bu yaklaşım ile anlamlandırılabileceğini söyleyebiliriz. Nitekim bölge ekonomisi tamamıla petrol üretimi ve ihracatına bağımlıdır, üretim yok denecek kadar azdır ve en önemli işveren de devlettir. Bölgedeki aşiretlerin çok büyük bir bölümünü kendisine eklemlemiş, nepotizme yaslanan ve siyasal çoğulculuğu yadsıyan bölgesel hükümet, Kürt kimliğine entegre ettiği bağımsızlık söylemi ve bölgesel güvenlik vurgusu ile rantçı yönetim anlayışını konsolide etmektedir.

Anahtar Kelimeler: Barzani, KDP, Enerji, Kerkük, Mahdavy.

\section{Kurdistan Regional Government: An Assessment within the Frame of the Rentier State Approach}

\begin{abstract}
Rentier state approach defines the states that acquire their whole income only through a natural resource. These states present an authoritarian type of profile and their people have a passive stance in terms of political/economic issues. When we assess Kurdistan Regional Government according to the rentier state approach, we could define this region as a rentier type of administration, however, not an independent state. For why economic development is fully dependent to oil production and exportation, industrial production could be seen as a minute amount and the most significant employer is the regional administration. Regional government, which has articulated vast majority of Kurdish tribes to its political will and has ignored pluralism, consolidates the rentier type of administration by the reference of Kurdish independence and the emphasis on regional security.
\end{abstract}

Keywords: Barzani, KDP, Energy, Kirkuk, Mahdavy. 


\section{Giriş}

2005 tarihli Irak Anayasası’na göre federe bir yönetimsel birim haline getirilen Kürdistan Bölgesel Yönetimi, Irak'ın yaşadığı toplumsal, ekonomik ve siyasal meseleler bağlamında uluslararası camiada adından en sık söz edilen aktörlerden biri haline gelmiştir. Etnik kimliğe yapılan atıf üzerinden Irak'ın genel olarak Arap kimliği/kültürü ve egemenliği üzerine oturmuş toplumsal/siyasal yapısından farklı bir görünüm arz ettiğini göstermeye çalışan ve bu amaçla ülkenin bağımsızlığından bu yana mücadele eden Iraklı Kürtler, ABD’nin Irak’a gerçekleştirdiği operasyon esnasında bu ülkeye verdikleri askeri/ siyasal desteğin karşıllğını, yeniden kurgulanan Irak'ın yönetimsel yapısı bağlamında federe bir statüye kavuşarak almışlardır. ABD'nin Irak’a düzenlediği operasyon sonrası Irak'ın en güvenli, istikrarlı ve kişi başına düşen gelirin en yüksek olduğu bölgesi haline gelen Kürdistan bölgesinin, petrol üretiminin artması ve doğalgaz rezervlerinin de kullanıma açılması sonrası ne tür bir geleceğe evrileceği Ortadoğu ekseninde üzerinde en çok durulan hususlardan biridir.

Ortadoğu ve petrol denildiği zaman üzerinde durulması gereken en önemli kuramsal yaklaşımlardan biri rantçı devlet (rentier state) yaklaşımıdır. Nitekim bu yaklaşım, enerji zengini Ortadoğu ülkelerindeki toplumsal/siyasal yapıyı ya da dönüşümü en iyi şekilde niteleyen hususlardan biri olarak son dönemde özellikle üzerinde durulan bir husus olmuştur. Ortadoğu coğrafyasındaki kabile/aşiret bağlılıklarına dayalı, çoğulcu demokrasiyi yadsıyan, güvenlikçi ve otoriter siyasal/ yönetimsel yapının gerisinde yatan toplumsal ve ekonomik arka planı yansıtabilmek amacıyla ortaya konmuş olan rantçı devlet yaklaşımı, enerji zengini bir coğrafya olarak orta vadede farklı bir görünüme evrilmesi beklenen Kürdistan Bölgesi'nin bugününe ve geleceğine dair çıarımlarda bulunabilme anlamında önemli bir altyapı unsuru olarak görülebilir.

$\mathrm{Bu}$ çalışmada, öncelikli olarak rantçı devlet yaklaşımının kuramsal öngörüleri üzerinde durulacaktır. Daha sonra ise Bölgenin toplumsal, siyasal ve ekonomik yapısına değinilecektir. Son olarak ise rantçı devlet yaklaşımı çerçevesinde bölgenin siyasal/yönetimsel yapısı ve muhtemel geleceği anlamlandırılmaya çalışılacaktır.

\section{Rantçı (Rantiyeci) Devlet Yaklaşımı}

İktisadi ilişkilerin temelini oluşturan kavramlardan biri olan rant, mülkiyet hakkına binaen toprak üzerinden kira elde edilmesi anlamına gelmektedir. Klasik anlamda değerlendirildiğinde toprak üzerinden ifade edilen rant, Doğu toplumlarında daha çok ganimet kavramı ile birlikte ele alınmıştır. Batı toplumlarında, öncelikle lord ile serf arasındaki üretim ilişkisi üzerinden değerlendirilen ve serf tarafından üretilen ürünün pazarda satılmasından elde edilen gelirden üretim maliyetlerinin çıarılması ile elde edilen karın adı olan rant, ${ }^{1}$ daha sonrasında David Ricardo tarafından toprağın verimliliği üzerinden ele alınmıştır. ${ }^{2}$ Marx, kullanım değeri ile değişim değeri arasındaki fark üzerinden artık değer şeklinde formüle ettiği rantı, sömürü ilişkisinin bir parçası olarak görmüştür. ${ }^{3}$

Bugün rant sözcügünden daha çok "ekonomik rant” kavramından bahsedilmekte ve ekonomik rantın da çok büyük bir oranda yeraltı kaynaklarından elde edildiği bilinmektedir. ${ }^{4}$ Zira doğal

1 İlyas Sözen, Kamil Uslu ve Volkan Öngel, “Ortadoğu ve Kuzey Afrika Ülkelerinin Rantiyeci Ekonomi Yapıları”, İstanbul Ticaret Üniversitesi Sosyal Bilimler Dergisi, Cilt 10, No.19, 2011, s.90.

2 David Ricardo, Principles of Political Economy and Taxation, R.M.Hartwell (der.), London, Penguin Books, 1971, s.91-92.

3 Ben Fine, “On Marx's Theory of Agricultural Rent", Economy and Society, Cilt 8, No.3, 1979, s.241-278.

4 Hossein Mahdavy, "Patterns and Problems of Economic Development in Rentier States: the Case of Iran”, M.A. Cook 
kaynaklar, herhangi bir çaba göstermeden satış aracılığıyla ciddi bir gelir getirmektedir. Bu gelire rant, geliri elde eden kişiye ya da kuruma da rantçı (rantiyeci) adı verilmektedir. Doğal kaynaklar açısından zengin olan ülkelerin toplumsal/siyasal istikrar ve barışın sağlanabilmesi ve korunabilmesi anlamında ciddi sıkıntılarla karşı karşıya kaldığını ya da kalabileceğini ifade eden "kaynak laneti” (resource curse) kavramı rantçı devlet yaklaşımına ilişkin tartışmalarda en fazla üzerinde durulan hususlardan biridir. ${ }^{5}$ Doğal kaynak sahipliğinin, bu kaynakların taşıdığı ekonomik ve stratejik değer nedeniyle o ülke toplumlarının kendi aralarında anlaşmazlığa sürüklenmesine ya da iç savaşa saplanmasına neden olmasının yanı sıra, o ülkeyi/ülkeleri dış etkiye ya da saldırılara daha açık hale getirdiğini kaydeden kaynak laneti, rantçı devlet tartışmasında önemli bir yer tutmaktadır. ${ }^{6}$ Kaynak laneti yaklaşımının altını çizdiği toplumsal anlaşmazlık, siyasal istikrarsızlık ve iç savaş gibi olumsuzlukların önünün alınması noktasında çoğulcu siyasal yapılanmanın ve bireysel/toplumsal özgürlüklerin iktidar tarafından baskılanması ve otoriter bir siyasal yapılanmanın kurumsallaştııılması durumu "rantçı devlet” yaklaşımını gündeme getirmektedir.

Engin Sune ve Ali Murat Özdemir, rantçı devlet yaklaşımını tarihsel/kuramsal dönüşüm süreci çerçevesinde dört kuşağa ayırmıştır. ${ }^{7}$ Hüseyin Mahdavy'nin ortaya attığı rantçı devlet yaklaşımı, tek bir doğal kaynak/emtia üzerinden gelir elde eden ülkelere referansla İran özelinde vurgulanmıştır. ${ }^{8}$ Mahdavy'e göre, devlet, doğal kayakların satışından/kiralanmasından elde ettiği geliri ülke içerisindeki egemen/etkin gruplar arasında paylaştırmaktadır. Ne var ki, bu paylaşım, toplumdaki üretici güçleri harekete geçirecek ve birikim süreçlerini harekete geçirecek bir nitelik taşımamaktadır. Yani Mahdavy'e göre, rantçı devletlerde üretim sürecini üstlenecek “yerel bir sanayi altyapısı” geliştirilemeyecektir. Mahdavy, üretici güçleri harekete geçiremeyen bu tarz ülkelerin, ciddi bir ekonomik birikim de sağlanamadığı için vergilendirme kıstasına da dayanmadığını, vergilendirmenin olmadığı bir ülkede de toplumsal sorumluluğa bağlı olarak devletten hak talebinde bulunacak bir toplumsal altyapının oluşmadığını belirtmektedir. ${ }^{9}$ Tıpkı Mahdavy gibi, birinci kuşak içerisinde yer alan Jacques Delacroix ise, rantçı devletleri "dağıtımcı devlet" olarak adlandırmıştır. ${ }^{10}$ Delacroix, petrol ve doğalgaz rezervlerinin sağladığı ranta dayalı bir yönetim yapısına sahip olan ülkelerde sınıf mücadelesinin/sömürüsünün varlığından da bahsedilemeyeceğini belirtmektedir. ${ }^{11}$ Burada Delacroix'in vurgulamaya çalıştı̆̆ husus, dağıtımcı devletlerde (rantçı devletler) etki alanını genişletmek isteyecek olan bürokrasinin düzenlemesi gereken kalıcı, etkin ve meşru bir sivil toplum anlayışının kurgulanamamış olmasıdır. ${ }^{12}$ Dağıtımın doğrudan devlet eliyle yapılıyor olması ve üretim/birikim süreçlerinin işletilememesi, sivil toplumu geliştirecek ve devleti sorgulayacak bir yerel burjuvazinin ortaya çıkmasını engellemektedir. Dünya sistemi yaklaşımının kuramsal öngörülerine vurgu yapan Delacroix’e göre, dağıtımcı devlet,

(der.), Studies in the Economic History of the Middle East: From the Rise of Islam to the Present Day, Oxford, Oxford University Press, 1970, s.428-467.

5 Jeffrey Frankel, “The Natural Resource Curse: A Survey”, Harvard Environmental Economics Program, Discussion Paper No.21, 2010; Michael L. Ross, “The Political Economy of the Resource Curse”, World Politics, Cilt 51, Ocak 1999, s.297-322.

6 Matthias Basedau, "Resource Curse or Rentier Peace? The Ambigous Effects of Oil Wealth and Oil Dependence on Violent Conflict", Journal of Peace Research, Cilt 46, No. 6, 2009, s.757-776; Steffen Hertog, "Defying the Resource Curse: Explaining Successful State-Owned Enterprises in Rentier States”, World Politics, Cilt 62, No.2, 2010, s.261-301.

7 Engin Sune ve Ali Murat Özdemir, "Rantçı Devlet Yazını Üzerine Deneme”, Uluslararası İlişkiler, Cilt 9, No.35, 2012, s.3-31.

8 Mahdavy, "Patterns and Problems", s.428-467.

9 Sune ve Özdemir, "Rantçı Devlet", s.7.

10 Jacques Delacroix, “The Distributive State in the World System”, Studies in Comparative International Development, Cilt 15, No.3, 1980, s.3-21.

11 Ibid., s.8.

12 Sune ve Özdemir, "Rantçı Devlet", s. 8. 
merkez ülkelerin, çevre ülkeler ekseninde bilinçli bir şekilde yarattığı bir yönetimsel yapıdır. Çevre ülkelerdeki devlet/iktidar elitlerinin merkez ülkelerin ekonomik işleyişleri açısından çok önemli olan doğal kaynakları çıkarabilmek için merkez ülkeler tarafından bu ülkelere yapılacak endüstri yatırımlarının güvenliğini sağlama yönünde etkin bir rol oynamaları küresel ekonomik işleyiş açısından çok değerlidir. Nitekim çevre ülkelerdeki yönetici elitlerin iktidarının sürekli olabilmesi için toplumsal/siyasal anlamda onların sorgulanmasını engelleyecek bir yönetim yapısının yaratılması gerekmektedir. ${ }^{13} \mathrm{Bu}$ da ancak dağıtımcı devlet yaklaşımının yansıttığı, üretmeyi ve biriktirmeyi yadsıyan yönetim anlayışı ile mümkün olmaktadır.

Giacomo Luciani ve Hazem Al Beblawi gibi isimler de bu alanda çalışarak kavramın içerisini doldurmaya çalışmışlardır. ${ }^{14} \mathrm{Bu}$ isimler, Sune ve Özdemir'e göre, "ikinci kuşak" rantçı devlet teorisyenleri olarak görülmektedir. Luciani, elde ettiği gelirin \%40’tan fazlasını belli bir dışsal rant aracılığıyla elde eden devletlerin "rantçı devlet" olarak adlandırılması gerektiğini ileri sürmüştür. ${ }^{15}$ Bu noktada ise, özellikle gelirinin büyük bir bölümünü petrol ve rezervlerinden elde eden Ortadoğu ülkelerini ön plana çıkarmıştır. ${ }^{16}$ Beblawi ve Luciani'ye göre bir devletin rantçı devlet olarak adlandırılması için ekonominin çok büyük bir oranda dışsal ranta dayalı olması ve doğal kaynakların çıkarılıp işlenmesi için gereken üretim tesisleri dışında ülke içerisinde kayda değer büyüklükte bir sanayi üretiminin olmaması gerekmektedir. Çalışan nüfusun ancak çok küçük bir bölümünün rant elde edilmesi sürecine dahil olmasına karşıllk o ülkenin nüfusunun büyük bir bölümünün ranttan elde edilen gelirin kullanılması ve dağıtılması sürecinde gündeme gelmesi ve ülke hükümetinin dışsal ranta el koyan ya da dışsal rantı kontrolü altında tutan başlıca aktör olması da Beblawi ve Luciani tarafından altı çizilen hususlardır. ${ }^{17}$ Luciani, yaptığı çalışmasında rantçı devletleri, "tahsisat devletleri” olarak da adlandırmaktadır. ${ }^{18}$ Bu ülkelerin yönetimleri, üretim süreci üzerinden yürüyen vergilendirme aracıllğıyla kendi toplumundan gelir elde etmemekte, dışarıdan elde ettiği geliri topluma dağıtarak onların zenginleşmesini sağlamaya çalışmaktadır. Luciani’ye göre, demokrasi, tahsisat devletlerinin toplumsal/siyasal meşruiyete eklemlenebilmesi bağlamında etken bir faktör değildir. Gelir kaynaklarını dışsal rant aracılığıyla değil de yurtiçi üretim ve vergilendirme üzerinden elde eden devletler ise Luciani tarafından "üretim devletleri” olarak adlandırılmaktadır. ${ }^{19}$ Luciani, demokratik anlayışın üretim devletlerine içkin bir unsur olduğunu, zira bu devletlerde halkın elde ettiği gelirin devlet dışı kaynaklardan elde edilip, vergilendirildiğini ifade etmektedir. ${ }^{20} \mathrm{Bu}$ devletlerde, ekonomi politikalarının da vergi gelirlerine dayalı olması, iktidarı elde etmek ve böylece ekonomi politikalarını düzenleyebilmek için farklı çıkar gruplarının demokratik bir anlayış çerçevesinde mücadele etmelerini beraberinde getirmektedir. Beblawi ise, rantçı devlet anlayışının çalışma ve ödül ilişkisini anlamsızlaştırdığını, bu çerçevede de bireyleşmeyi ve dolayısıyla yurttaşlaşmayı önlediğini

13 Engin Sune, "Defining the Different: A Critical Analysis of the Rentier, Failed and Rogue State Theories", Ortadoğu Teknik Üniversitesi Sosyal Bilimler Enstitüsü, Yayımlanmamış Yüksek Lisans Tezi, Ankara, Temmuz 2012, s.10-11.

14 Hazem Beblawi ve Giacomo Luciani, The Rentier State: Nation, State and Integration in the Arab World, London, Croom Helm ve Istituto Affari Internazionali, 1987.

15 Giacomo Luciani, “Allocation vs. Production States: A Theoretical Framework”, Giacomo Luciani (der.), The Arab State, London, Routledge Publishing, 1990, s.72.

16 Nuri Yeşilyurt, “Ortadoğu'da Rejim Güvenliği ve Küçük Devlet”, Ankara Üniversitesi Sosyal Bilimler Enstitüsü, Yayımlanmamış Doktora Tezi, Ankara, 2013, s.100-105.

17 Hazem Al Beblawi, “The Rentier State in the Arab World”, Giacomo Luciani (der.), The Arab State, London, Routledge Publishing, 1990, s.89; Luciani, "Allocation vs. Production", s.71-72.

18 Luciani, "Allocation vs. Production States", s.65-84.

19 Ibid.

20 Sune ve Özdemir, "Rantçı Devlet”, s.11. 
belirtmektedir. Bu tip toplumlarda kazanç, öncelikli olarak, devletin/iktidarın üst düzey pozisyonlarını tutmuş ya da iktidara etkin bir şekilde destek veren hükümet üyeleri, aşiretler/kabileler ve ailelere aktarılmaktadır. Böylece hiyerarşik bir toplumsal/siyasal yapı oluşmaktadır. ${ }^{21}$ Aynı kuşak içerisinde görülebilecek olan Jill Crystal ise, bir devletin rant gelirinin dramatik bir şekilde artmasına paralel olarak, daha önce ülke siyasetinde etkili olan belli aktörlerin, ekonomik kazançlarında yaşanacak ciddi bir artışa paralel olarak siyasal etkinliklerinin azalmasını ya da iktidar eliyle azaltılmasını gönüllü olarak kabul edebileceklerini belirtmektedir. ${ }^{22}$

Kiren Aziz Chaudhry ve Gwenn Okruhlik ise rantçı devlet yaklaşımına yön veren ve 1990 'lı yıllarda beliren üçüncü kuşak teorisyenler arasında en önemlileridir. Chaudhry, özellikle Irak ve Suudi Arabistan özelinde yaptığı analizler ekseninde, tamamıyla rant geliri üzerinde duran yaklaşımlardan uzaklaşarak tarihsel, toplumsal/sosyal altyapıyı da analize katmış ve bu altyapının rant gelirini dağıtma/ kullanma aşamasında karar alıcılar üzerinde ciddi anlamda etkide bulabileceğinden bahsetmiştir. Chaudhry, Suudi Arabistan ve Irak'ta 1980'lerin sonu itibarıyla piyasa ekonomisine ilişkin reformların başarısızlığa uğramasının en önemli nedenini, yalnızca 1980'lerin başında düşen petrol fiyatları (dışsal rant) üzerinden değil, aynı zamanda, bu devletlerde özellikle 1970’li yıllar boyunca uygulanan katıksız devletçilik anlayışının da bir sonucu olarak görmektedir. Yani dışsal faktörler ile içsel faktörleri birlikte ele almaktadır. ${ }^{23}$ Okruhlik ise, özellikle Ortadoğu'da yer alan rantçı devletlerde, toplumsal/ siyasal muhalefetin tam anlamıyla ortadan kaldırıldığını söylemenin mümkün olmadığını, rantın eşitsiz bir şekilde dağıtımı devam ettiği müddetçe muhalefetin ve belli oranda siyasal istikrarsızlığın da varolacağını belirtmektedir. Okruhlik'e göre, Suudi Arabistan'da rantın dağıtımından yeterli oranda pay alamayan Şiilerin huzursuzluğu bunun açık bir örneğidir. ${ }^{24}$

Sune ve Özdemir'in rantçı devlet yaklaşımı bağlamında altını çizdiği dördüncü kuşak ise özellikle Pete W. Moore'un analizleri üzerinden şekillenmiştir. Moore’a göre, rantçı devletlerde de iş çevreleri ile siyasal yapı arasında ciddi bir etkileşim vardır. Moore, özellikle Ortadoğu ülkeleri ekseninde yaptığı değerlendirmede, iş çevreleri ile yönetici elit arasında bir ittifakın oluşturulduğu hallerde, iktidarın dağıtımcı rolünün daha etkin bir şekilde işlediğini belirtmektedir. ${ }^{25}$ Yani, ona göre, iktidar ile iş çevreleri arasındaki ilişkiler ne kadar iyiyse, rantçı devlete ilişkin işleyiş de o kadar sağlıklı olmaktadır. Herb ise konuya farklı bir açıdan yaklaşmış ve kamu harcamalarının Gayri Safi Yurtiçi Hâsıla (GSYH) içerisindeki oranı ne kadar yüksekse, o ülkenin rantçı devlet olma ihtimalinin de o kadar fazla olduğunu ifade etmiştir. ${ }^{26}$

Kavram daha çok doğal kaynaklar (günümüzde daha çok petrol, doğalgaz ve kıymetli taşlar) üzerinden tanımlanıyor olsa da finansal anlamda oldukça güçlü ve uluslararası ticaretin gidişatına yön veren bir ülkenin para birimi (ABD’nin gücüne paralel olarak uluslararası finans ve ticaretin dolar üzerinden yürütülmesi) ya da bir ülkenin topraklarında bulundurduğu stratejik öneme haiz askeri üsler de bu bağlamda ele alınabilir. Bunun yanı sıra, bir ülkenin yurtdışında yaşayan/çalışan vatandaşları

21 Beblawi, “The Rentier State”, s.88-89; Sune ve Özdemir, "Rantçı Devlet”, s.13-14.

22 Jill Crystal, "Coalitions in Oil Monarchies: Kuwait and Qatar”, Comparative Politics, Cilt 21, No.4, 1989, s.427-443.

23 Kiren Aziz Chaudhry, "Economic Liberalization and the Lineages of the Rentier State", Comparative Politics, Cilt 27, No.1, 1994, s.1-25; Sune ve Özdemir, "Rantçı Devlet”, s.17.

24 Gwenn Okruhlik, "Rentier Wealth, Unruly Law and the Rise of Opposition: The Political Economy of Oil States", Comparative Politics, Cilt 31, No.3, 1999, s.295-315; Sune ve Özdemir, "Rantçı Devlet”, s.18.

25 Pete W. Moore, "Rentier Fiscal Crisis and Regime Stability: Business-State Relations in the Gulf”, Studies in Comparative International Development, Cilt 37, No.1, 2002, s.256-285.

26 Michael Herb, “Does Rentierism Prevent Democracy?”, Annual Meeting of the American Political Science Association (2002), 29 Ağustos-1 Eylül 2002, http://www2.gsu.edu/ polmfh/herb_2002_apsa.pdf, (Erişim Tarihi 14 Kasım 2014). 
tarafından gönderilen döviz gelirleri, o ülkenin gelirinin büyük bir bölümünü oluşturuyorsa, o döviz gelirleri de rant bağlamında ele alınabilmektedir. ${ }^{27}$

Rantçı bir yapıya sahip olan devletlerde mevcut siyasal sistemin devamlılığının sağlanabilmesi için rant üzerinden elde edilen gelirin sürekliliğinin sağlanması mutlak bir zorunluluktur. Zira bu devletler, gelir elde etme hususunda yurtiçi kaynaklar noktasında herhangi bir beklenti içerisinde değildir. ${ }^{28}$ Sahip olunan doğal kaynaklar özelinde yaratılan dışsal rant ekonominin gerek duyduğu kaynağı yarattığı sürece yurtiçi üretim üzerinden gelir elde etme zorunluluğu ortadan kalktığı için, devletin vatandaşlarına olan ekonomik bağımlılığı da azalmaktadır. Hatta dışsal rant, kamu harcamalarının karşılanabilmesi ve belli bir toplumsal refah düzeyinin yaratılabilmesi bağlamında yeterli olduğu için, rantçı devletlerin kendi vatandaşlarını vergilendirme hususunu dahi rafa kaldırdıklarını görüyoruz. ${ }^{29} \mathrm{Bu}$ devletlerin güvenliği, toplumsal refah düzeyi ve kalkınma projeleri için gerekli olan ekonomik girdi belli bir doğal kaynağın/ kaynakların satışından elde edilen gelire bağlı olduğu için, o kaynağın fiyatında yaşanabilecek fiyat dalgalanmaları ya da üretim düzeyinde yaşanabilecek bir düşüş ekonomik işleyişi alt üst etme kapasitesine sahiptir. Böyle bir durumda, rant gelirine dayalı kalkınma projeleri, endüstriyel yatırımlar, imar projeleri ve sübvansiyonlar durdurulabilmekte ya da yarıda kalabilmektedir. ${ }^{30}$

Daha önce de ifade ettiğimiz üzere, dışsal ranta dayalı bir siyasal/ekonomik görünüme sahip olan devletlerde nüfusun çok küçük bir bölümü üretim sürecinde yer almaktadır. ${ }^{31}$ Ancak bu durum, ülke nüfusunun/iş gücünün verimliliğini azaltan ve nüfusun üretim sürecinde etken değil, edilgen bir ön kabule sürükleyen bir sürece işaret etmektedir. ${ }^{32}$

$\mathrm{Bu}$ devletlerde ranttan elde edilen gelir doğrudan devletin/iktidarın eline geçmekte ve onun aracılığıyla dağıtılmaktadır. Bu nedenle, iktidarda bulunan kişi/grubun ülke içerisindeki ekonomik ve siyasi etkinliği tartışılamaz bir hale gelmektedir. İktidarı elde tutan ve rant gelirini dağıtmakla görevli kişi/grup, bu gelirin süreklilik taşıyacağı ve hatta zaman içerisinde artabileceği ön kabulü ile hareket etmekte ve kendi iktidarının devamlılığ için, bu gelirin büyük bir bölümünü, taraftar kazanabilmek ya da kendisine destek verenlerin memnuniyetleri ile bağlılıklarını sürekli hale getirebilmek için kullanmaktadır. ${ }^{33} \mathrm{Bu}$ durum, özellikle devlet bürokrasisinde görev yapanların maaşlarına ciddi bir artış olarak yansıdığı gibi, aynı zamanda devletin en önemli işveren haline gelmesine de neden olmaktadır. $\mathrm{Bu}$ bağlamda, rantçı devletlerin bürokrasileri gereksiz bir büyüklüğe sahip olmakta ve kendisini yaratan siyasal anlayışa ya da aktöre aşırı bağımlı ve esnek olmayan bir konuma eklemlenmektedir. ${ }^{34}$

Hem üretim yönünde bir baskı/istek olmaması hem gelirin devlet tarafindan yeterli oranda dağıtılıyor olması hem de vergilendirmenin olmaması, bu ülke vatandaşlarının siyasal temsil hususunda isteksiz bir görünüme bürünmelerine neden olmaktadır. Yani ranttan elde edilen ve topluma dağıtılan gelir

27 Onur Bilgen, "Petrol ve Suudi Arabistan: Bir Lütuf Mu, Yoksa Bela Mı?”, Akademik Ortadoğu, Cilt 5, No.1, 2010, s.25-42.

28 Rolf Schwarz, "The Political Economy of State Formation in the Arab Middle East: Rentier States, Economic Reform and Democratization", Review of International Political Economy, Cilt 15, No.4, 2008, s.599-621.

29 Camilla Sandbakken, "The Limits to Democracy Posed By Oil Rentier States: The Cases of Algeria, Nigeria abd Libya”, Democratization, Cilt 13, No.1, 2006, s.137.

30 Bilgen, “Petrol ve Suudi Arabistan”, s.27.

31 E.Roger Owen, "One Hundred Years of Middle Eastern Oil”, Middle East Brief, No.24, Brandeis University Crown Center for Middle East Studies, Ocak 2008, s.4-6.

32 Michael L.Ross, “Does Oil Hinder Democracy?”, World Politics, Cilt 53, No.3, 2001, s.325-361.

33 Mahmood Ghaffar, "Clientalism Within the Arabian Gulf States and Beyond”, Central European Journal of International and Security Studies, No.1, 2014, s.30-51.

34 Michael Herb, "A Nation of Bureaucrats: Political Participation and Economic Diversification in Kuwait and the United Arab Emirates", International Journal of Middle East Studies, Cilt 41, No.3, 2009, s.375-395. 
sayesinde sosyal refah ortamı oluşturulduğu için toplumun siyasal sistemi sorgulamaya yönelik istekliliği bastırılmakta ve siyasal katılım talebi de olabilecek en alt düzeyde tutulabilmektedir. Ortadoğu'da, Suudi Arabistan başta olmak üzere, özellikle Basra Körfezi çevresinde kümelenmiş olan Arap devletleri, rantçı devletlerin bu temel özelliğini yansıtan en sağlıklı örnekler olarak görülmektedir. ${ }^{35}$

Vergilendirme olmaması ve etkin bir siyasal temsil ile değişime kapalı bir görünüme sahip olması, uzun vadede, devlet ile toplum arasındaki duygusal ve siyasal bağların kopmasına ve bu iki birimin birbirinden tamamıyla ayrı olarak değerlendirilebilmesine neden olabilmektedir. Üstelik rantçı devletlerde elde edilecek gelir tamamıyla rantın elde edildiği ülke/ülkelerin gelirine bağımlı olduğu için, rantçı devlet ekonomik anlamda tamamıla bağımlı bir görünüme bürünebilir. Hatta bu durum, uzun vadede ülkenin siyasal varlığını ve bağımsızlı̆̆ını tehdit edecek bir hale de gelebilir. Ranttan elde edilen gelir ile yapılan kamu harcamalarının şeffaflığını denetleyebilecek sivil bir otoritenin olmaması gelirin belli isimlerin/ailelerin kontrolüne geçmesine de neden olabilmektedir. ${ }^{36}$

Bu devletlerde, iktidar, halkın desteğini alabilmek ya da sadakatine sahip olabilmek için, vergi almamanın yanı sıra, Shambayatinin de belirttiği üzere, kamu harcamalarını arttırıp sosyal refahı yükseltmeye yönelik projelere girişebilir. ${ }^{37}$ Nitekim halkın yaşam standardının yükseltilmesine paralel olarak toplumsal huzursuzluklar azaltılabilir, demokratik temsil ya da siyasal çoğulculuk hususunda gelebilecek talepler ortadan kaldırılabilir ve mevcut iktidar siyasal meşruiyetini koruyabilir. Yani rantçı devletlerde toplumun refah düzeyinin arttırılması ile demokrasinin lafzına uygun çoğulcu bir siyasal yapı talebi arasında negatif bir ilişki bulunmaktadır.

Muhalifkanatta yer alabileceği değerlendirilen belli kişi ve grupların sadakatlerini kazanabilmek için, rant gelirini bu grupları susturabilmek amacıyla kullanan, ihaleleri ve ticari lisansları kendisine sadık kalanlara vereceğini gösteren ve onların refahının arttırılması ile toplumun geniş kesimlerinin hükümete/devlete karşı yönlendirebileceği muhalif talepleri bastırabileceğini düşünen rantçı devletler, ekonominin her alanında devlet izni, desteği ve korumasını zorunlu bir hale getirerek otoriter siyasal anlayışın ekonomik altyapısını da inşa etmektedir. ${ }^{38}$

\section{Kürdistan Bölgesi’nin Toplumsal, Ekonomik ve Siyasal Görünümü}

\section{Toplumsal ve Siyasal Görünüm}

Kürtlerin siyasal/yönetimsel özerklik taleplerinin geçmişi Şeyh Mahmud Berzenci'nin 1920'li yılların başlarında İngiltere'nin kontrolündeki Irak yönetimine karşı giriştiği ayaklanmalar ${ }^{39}$ ve bu bölgede bağımsız bir Kürt devletinin kurulması yönünde Milletler Cemiyeti’ne yapılan başvuruya kadar uzanmaktadır. ${ }^{40}$ II. Dünya Savaşı yıllarında Irak’ın kuzeyinde yeniden güçlenen Kürt varlığı, savaş

$35 \mathrm{Bu}$ devletlerin en önemlileri ise Kuveyt, Katar, Birleşik Arap Emirlikleri (BAE) ve Bahreyn'dir. Bkz. Aydın Aydın, "Hereditary Oil Monarchies: Why Arab Spring Fails in GCC Arabian States?", SDÜ Fen Edebiyat Fakültesi Sosyal Bilimler Dergisi, No.30, Aralık 2013, s.123-138.

36 Matthew Gray, "A Theory of Late Rentierism in the Arab States of the Gulf”, Center for International and Regional Studies Occasional Paper, No.7, 2011, s.23-25.

37 Hootan Shambayati, “The Rentier State, Interest Groups and the Paradox of Autonomy: State and Business in Turkey and Iran", Comparative Politics, Cilt 26, No.3, 1994, s.308-309.

38 Ghaffar, "Clientalism within”, s.30-51.

39 Selçuk Ural, “Mütareke Döneminde İngiltere’nin Güneydoğu Anadolu Politikası”, Ankara Üniversitesi Türk İnkılap Tarihi Enstitüsü Atatürk Yolu Dergisi, No.39, 2007, s.434-435.

40 Ayşe Hür, “Osmanlı'dan Bugüne Kürtler ve Devlet: Kürt Milliyetçiliğinin Geç Doğumu”, SETA, http://arsiv.setav.org/ ups/dosya/27464.pdf (Erişim Tarihi 28 Aralık 2014). 
sonrasında, SSCB’nin de desteğiyle İran'ın kuzeybatısında oluşturulan ve Irak Kürtlerinin en önemli lideri olarak görülen Molla Mustafa Barzani'nin ${ }^{41}$ de yönetiminde yer aldığı Mahabad Cumhuriyeti eliyle ciddi bir siyasal meşruiyete de kavuşmuştur. ${ }^{42} \mathrm{Ne}$ var ki, bu devletin 1 yıl dahi yaşayamadan İran ordusunca ortadan kaldırılması Iraklı ve İranlı Kürt ulusçuları arasındaki bağlantının ciddi anlamda zarar görmesine yol açmıştır. 1960-1970 yılları arasında ise Molla Mustafa Barzani’nin önderliğindeki Kürt aşiretlerinin ciddi bir yönetimsel istikrarsızlık yaşayan Irak Yönetimi’ne karşı geniş çaplı bir isyan hareketi sürdürdügünü görüyoruz. Bu hareket, 1970 yılı itibarıyla olumlu bir sonuca ulaşmış ve Irak'in kuzeyinde Erbil merkezli otonom bir yapının oluşturulacağına dair bir antlaşma imzalanmış olmasına karşın, ${ }^{43}$ Bağdat yönetiminin, İran ile işbirliği yaptıkları gerekçesiyle, Irak Ordusu’nu Kürtlerin üzerine göndermesi neticesinde bu otonomi girişimi 1974 yılı itibarıyla sonlanmıştır. ${ }^{44}$ Iraklı Kürtler, Irakİran Savaşı (1980-88) esnasında ve sonrasında da siyasal/yönetimsel özerklik elde etmeye yönelik eylemlerini sürdürmüş ve geniş çaplı bir isyan hareketi ile istediklerini elde etmeye çalışmışlardır. Ne var ki, Irak Hükümeti’nin bu eylemliliğe cevabı çok sert olmuştur. Enfal Operasyonu adı verilen ve kimyasal silahların da kullanıldığı geniş çaplı katliamlar sonucunda binlerce Iraklı Kürt öldürülmüşs, ${ }^{45}$ Kürtlerin yaşadığı çok sayıda kasaba ve köy yakılıp, yıkılmış ve Halepçe'de gerçekleştirilen kimyasal saldırı esnasında çoğu kadın ve çocuk binlerce insan hayatını kaybetmiştir. ${ }^{46}$

Birinci Körfez Savaşı esnasında Saddam Hüseyin’e karşı bir kez daha ayaklanan Kürtleri Irak Ordusu'nun gerçekleştirebileceği yeni katliamlardan koruyabilmek amacıyla BM Güvenlik Konseyi'nin aldığg 688 sayılı karar gereğince 36. paralelin kuzeyinde yer alan Irak toprakları "uçuşa yasak bölge" ilan edilerek Irak Ordusu'na kapatılmıştır. ${ }^{47}$ 36. paralelin bir sınır olarak belirlenmesi neticesinde Erbil, Dohuk ve Süleymaniye vilayetleri ekseninde bir Kürt siyasal varlığının oluşumu noktasında adım atılmıştır. Bu durum, Iraklı Kürtlerin, Irak'ın geri kalan bölümünden ve Bağdat hükümetinden de facto bağımsız hareket etmelerini sağlayacak bir siyasal/yönetimsel yapının hayata geçirilmesi anlamında önemli bir adım olmuştur. Nitekim 1992 yılı itibarılyla bölgesel bir parlamento kurulmuş ve ilk bölgesel seçimler de Haziran 1992 'de gerçekleştirilmiştir. ${ }^{48}$ Seçimler sonucunda Kürdistan Demokrat Partisi (KDP) ile Kürdistan Yurtseverler Birliği (KYB)'nin güç eşitliğine dayalı iki partili bir siyasal yapı belirmiştir. Bağdat, bölgeye yönelik bir ekonomik ambargo uygulamasına girişip petrol ve gıda sevkiyatını durdurunca bölgedeki huzursuzluk artmış, bu durum, bölgenin iki temel siyasal aktörü Mesud Barzani’nin kontrolündeki KDP ile Celal Talabani’nin liderliğini yaptığı KYB arasındaki siyasal hâkimiyet mücadelesi ve silahlı çatışma ile birleştiği noktada ciddi bir kriz ortamı yaratmıştır (1994-1996). ${ }^{49} \mathrm{Ne}$ var ki, BM tarafından ilan edilen "petrol karşılığı

41 Zafer Yıldırım, “1932-1975 Dönemi Irak’ın Ulus Devlet Yapısını Sarsan İsyancı Bir Hareket Olarak Barzaniler ve Irak Kürdistan Demokrasi Partisi”, Akademik Ortadoğu, Cilt 1, No.2, 2007, s.166.

42 William Aegleton Jr., Mehabad Kürt Cumhuriyeti 1946, Emin Bozarslan (Çev.), İstanbul, Koral Yayınları, 1976.

43 Saad N. Jawad, “The Iraqi Constitution: Structural Flaws and Political Implications”, LSE Middle East Centre Paper Series, No.1, Kasim 2013, s.7.

44 "War in Iraq: What's Next For the Kurds?", International Crisis Group, No.10, Mart 2003, s.2.

45 Joost R. Hiltermann, “The 1988 Anfal Campaign in Iraqi Kurdistan”, Online Encyclopedia of Mass Violence, Şubat 2008, http:// faculty.washington.edu/goldberg/The-1988-Anfal-Campaign-in-Iraqi-Kurdistan.pdf (Erişim Tarihi 28 Arallk 2014).

46 Judit Neurink, "The Gassing of Halabja Turned the Card on the Kurds in 1988”, Rudaw, 15 Mart 2014, http://rudaw. net/english/kurdistan/150320141 (Erişim Tarihi 27 Aralık 2014).

47 “Resolution 688”, http://daccess-dds-ny.un.org/doc/RESOLUTION/GEN/NR0/596/24/IMG/NR059624.pdf? OpenElement (Erişim Tarihi 28 Aralık 2014).

48 Hanna Yousif Freij, "Alliance Patterns of a Secessionist Movement: the Kurdish Nationalist Movement in Iraq", Journal of Muslim Minority Affairs, Cilt 18, No.1, 2007, s.28-32.

49 Michiel Leezenberg, "Iraqi Kurdistan: Contours of a Post-Civil War Society", Third World Quarterly, Cilt 26, No.4-5, 2005, s.631-647. 
gıda” programından gelen gelirin bir bölümünün (\%13'lük kısmı) Irak'ın kuzeyine ayrılıp, KDP ile KYB arasındaki anlaşmazlık da 1998 tarihli Washington Antlaşması ile sona erdirilince, ${ }^{50}$ Kürt ulusçuluğunun siyasal yükselişi devam etmiştir. De facto olarak oluşan Kürt siyasal varlığı; parlamento, bayrak, ulusal marş ve yönetimsel birimlerin teşkilatlandırılması ile süreklilik arz eden bir gelişim seyrine kavuşmuştur. Transit ticaretten elde edilen gelir ve özellikle Dohuk ve Zaho merkezli olarak gerçekleştirildiği ifade edilen silah ticareti ile kaçakçılık, ${ }^{11}$ BM'nin uyguladığı petrol karşılığı gıda programına eklemlenerek Irak'ın kuzeyindeki Kürt varlığının ekonomik olarak ayakta kalmasını sağlayan unsurlar olmuştur.

Irak’taki Kürt siyasal varlığına ilişkin algıyı tamamıyla değiştiren gelişme ise 2003 yılında gerçekleştirilen II. Körfez Harekâtı olmuştur. Saddam'ın devrildiği bu operasyon esnasında ABD’nin Irak'taki en önemli müttefiki haline gelen Iraklı Kürtler, Irak'ı federal bir yönetim haline getiren ve kendilerini de "Kürdistan Bölgesi” adıyla anayasal karşılığı olan "federe" bir yönetimsel birim olarak teşkilatlandıran 2005 tarihli Irak Anayasası ile siyasal taleplerini karşılayabilme yönünde çok önemli bir adım atmışlardır. ${ }^{52}$ Kürdistan Bölgesi, Irak’ın içerisine sürüklendiği etnik ve özellikle de dinsel/mezhepsel gerilim ve çatışmalar sonrasında ülkenin en güvenli yeri haline gelmiştir. Kürtler, Araplar ve Türkmenlerin birbirlerine çok yakın nüfusa sahip olduğu petrol zengini Kerkük ${ }^{53}$ ve çevresinin kime ait olacağı konusu Bağdat'taki merkezi hükümet ile Erbil'in arasının açılmasına yol açmaktadır. 2003 yılındaki ABD işgalinin ardından Kürtlerin yoğun bir şekilde göç ederek demografik yapıyı değiştirmeye çalıştıkları ve Kürt lider Celal Talabani tarafından “Kürtlerin Kudüs'ü” olarak adlandırılan ${ }^{54}$ Kerkük'ün statüsü, 2005 tarihli Irak Anayasası́nın 140. maddesine göre referandum ile belirlenecekti. ${ }^{55} \mathrm{Ne}$ var ki, bu referandumun hangi sınırlar dâhilinde gerçekleştirileceği, referanduma konu olacak demografik yapının hangi tarihi esas alacağı ve ne tür sorular ile sürecin yürütüleceğine ilişkin belirsizlik halen devam etmektedir. Nitekim bölgeye yönlendirilen Kürt nüfus aracıllğıyla, Kürt nüfusunun, Arap ve Türkmenlerin nüfusundan fazla hale getirilmek istendiği de göz önünde bulundurulduğunda Kürdistan Bölgesi’nin referandumu kazanmayı hedeflediği ortadadır. ${ }^{56}$ Irak-Şam İslam Devleti (IŞIDD ya da İslam Devleti-İD) adlı terör örgütünün başta Musul olmak üzere Irak'ta gerçekleştirdiği işgaller esnasında bölgede güvenliği sağlayabilmek amacıyla, Kerkük'ü kontrolü altına alan ${ }^{57}$ ve Irak'taki toplumsal/siyasal parçalanmışlığı kendisi için çok önemli olan bu şehri ele geçirerek

50 Alan Makovsky, "Kurdish Agreement Signals New US Commitment", The Washington Institute, Policywatch No.341, Eylül 1998, http://www.washingtoninstitute.org/policy-analysis/view/kurdish-agreement-signals-new-u.s.-commitment (Erişim Tarihi 29 Aralık 2014).

51 "Lack of Authority in Northern Iraq Increases Arm Smuggling”, Today's Zaman, 16 Ağustos 2004, http://www.todayszaman. com/national_lack-of-authority-in-n-iraq-increases-arm-smuggling_11483.html (Erişim Tarihi 28 Aralık 2014).

52 "Iraqi Constitution", http://www.iraqinationality.gov.iq/attach/iraqi_constitution.pdf (Erişim Tarihi 29 Aralık 2014).

53 Uluslararası Enerji Ajansı́na (IEA) göre, Irak'taki mevcut petrol üretiminin \%40'^ Kerkük'te gerçekleşmektedir. Bunun yanı sıra ülkenin kanıtlanmış petrol rezervlerinin \%6'sı Kerkük ve çevresinde konumlanmıştır. Hatta Kerkük'ün potansiyel petrol rezervinin ülkenin toplam petrol rezervine oranının \%14 olduğunu kaydeden analizler de mevcuttur. Kerkük-Yumurtalık Petrol Boru Hattı ise hem Irak hem de Kürdistan Bölgesi’nin ekonomik görünümü açısından çok önemli bir noktada durmaktadır. 1977'de açılan ve yıllık taşıma kapasitesi 70,9 milyon ton olan bu hattan günlük 120 bin varillik petrol Türkiye’ye pompalanmakta ve oradan da dünyaya pazarlanmaktadır. Bkz. “Kerkük Neden Önemli?”, Al Jazeera, 24 Haziran 2014, http://www.aljazeera.com.tr/haber/kerkuk-neden-onemli, (Erişim Tarihi 20 Kasım 2014).

54 Bill Park, Modern Turkey: People, State and a Foreign Policy in a Globalized World, Abingdon, Routledge Publishing, 2012 , s.88.

55 Brendan O’Leary ve David Bateman, “Article 140: Iraq's Constitution, Kirkuk and the Disputed Territories”, KNCNA, Mayıs 2008, http://www.kncna.org/docs/pdf_files/oleary_paper.pdf (Erişim Tarihi 29 Aralık 2014).

56 Michael Knights ve Ahmed Ali, "Kirkuk in Transition: Confidence Building in Northern Iraq", The Washington Institute, Policy Focus No.102, Nisan 2010.

57 Tuğçe Varol Sevim, "Rethinking Past, Today and Future of Kirkuk and its Black Gold”, European Journal of Research on Education, 2014, s.12-16. 
değerlendirmek isteyen Kürdistan Bölgesi yönetiminin "bağımsızlık” yönündeki söylemlerini arttırdığı da görülmektedir. ${ }^{58}$ Nitekim Erbil, bu hususta uluslararası bir destek sağlayabilmek için temaslarda bulunmaya başlamış, ancak, şimdilik kaydıyla bu ihtimalin uzak olduğunu görmüştür. ${ }^{59}$

Mevcut nüfusunun 5 milyondan fazla olduğu belirtilen, ancak bu rakam konusunda da tartışmaların yaşandığ ${ }_{1}{ }^{60}$ Kürdistan Bölgesi, yalnızca Kürtlerin yaşadığı bir bölge değildir. Türkmenler, Ezidiler ve Hıristiyan olan Keldaniler ile Süryaniler de bu topraklarda yaşamlarını sürdürmektedir. ${ }^{61}$ Hatta 2003 yılındaki ABD müdahalesinin ardından beliren etnik/dinsel çatışmalar nedeniyle başta Bağdat ve Musul'dan olmak üzere çok sayıda Hıristiyan ülkenin en istikrarlı ve güvenli bölgesi olarak görülen Kürdistan Bölgesi’ne sığınmıştır. IŞİD’in Irak'taki ilerleyişi ve gerçekleştirdikleri katliamlar da Irak'ın batı ve orta kesimlerinden bölgeye olan Türkmen ve Ezidi göçünü tetiklemiştir. ${ }^{62}$ Farklı etnik ve dinsel grupların varlığına karşın, bölge nüfusunun büyük bir bölümünü Kürtlerin oluşturuyor olması ve bölgesel yönetimin de Kürt ulusal kimliği ile eşleniyor oluşu, bölgedeki varlığı asırlar ile ifade edilen diğer toplumsal grupların sosyal ve siyasal anlamda birer azınlık olarak görülmelerine neden olmaktadır. Kürtler ile onların ardından bölgede en yoğun nüfusa sahip olan Türkmenler arasındaki toprak tabanlı yönetimsel anlaşmazlık, Kerkük ve çevresindeki kasabaların siyasal geleceği ile Türkmenlerin bölgesel yönetim içerisindeki rolünün/katılımının ne olacağı gibi hususlar değerlendirildiğinde gündeme gelen en önemli toplumsal sorun olarak belirmektedir. Üstelik bu sorunun varlığı, Türkiye’nin Iraklı Türkmenler ile olan doğal yakınlığı ile birlikte değerlendirildiğinde Türkiye-Kürdistan Bölgesi ilişkilerini her iki taraf açısından da olumlu/olumsuz etkileme kapasitesine sahip "güvenlikçi” bir dış politika algısı yaratmaktadır. ${ }^{63}$

Kürdistan Bölgesi, son dönemde Gorran gibi farklı sesler de belirmiş olmasına karşın, uzun bir süre iki partinin siyasal koalisyonuna dayalı bir yönetimsel yapı ekseninde şekillenmiştir. Barzani ailesinin liderliğini yaptığı ve milliyetçi-muhafazakâr bir yapıyı yansıtan KDP ile Celal Talabani’nin liderliğinde şekillendirilmiş ve sosyal-demokrat bir programı savunurken Kürt ulusçuluğunu da yadsımayan KYB arasında Washington Antlaşması ile oluşturulmuş siyasal ittifak, Kürdistan Bölgesi'nin federe bir birim olarak kurgulanması ile bir üst perdeye taşınmıştır. Kürdistan Bölgesi, 4 yılda bir düzenlenen seçimler ile temsilcileri belirlenen 111 sandalyeli bir parlamentoya sahiptir. 111 sandalyeden 11’i bölgesel azınlık olarak görülen Türkmen, Asurî (Keldani ve Süryani) ve Ermenilere

58 Ayub Nuri, "Why Kurdish Independence is the Only Solution For the World?”, Time, 16 Ağustos 2014, http://time. com/3105066/kurdish-independence-iraq (Erişim Tarihi 29 Kasım 2014). "Massoud Barzani: ISIS Fight Trumps Independence for Now”, Rudaw, 13 Ekim 2014, http://rudaw.net/english/kurdistan/131020141 (Erişim Tarihi 29 Kasim 2014).

59 Henri J.Barkey, “Kurdish Independence: One Day, But Certainly Not Now”, The American Interest, 8 Ağustos 2014, http://www.the-american-interest.com/2014/08/08/kurdish-independence-one-day-but-certainly-not-now (Erişim Tarihi 28 Kasım 2014); Helene Cooper ve Michael R.Gordon, "Iraqi Kurds Expand Autonomy as ISIS Reorders the Landscape”, The New York Times, 29 Ağustos 2014, http://www.nytimes.com/2014/08/30/world/middleeast/iraqikurds-expand-autonomy-as-isis-reorders-the-landscape.html?_r=0 (Erişim Tarihi 30 Kasım 2014).

60 Abdel Hamid Zebari, “Opposition in Iraqi Kurdistan Questions Population Figures”, Al Monitor, 26 Haziran 2013, http://www.al-monitor.com/pulse/originals/2013/06/kurdistan-region-abnormal-population-growth.html (Erişim Tarihi 30 Kasım 2014).

61 Serhat Erkmen ve Oytun Orhan, “Kuzey Irak’n Toplumsal, Siyasal Yapısı ve Kürt Bölgesel Yönetimi’nin Türkiye İle İlişkileri”, ORSAM Rapor, No.40, 2011, s.7-9.

62 Firuze Yağmur Gökler, “IŞİD Operasyonları Sonrası Irak’ta İnsani Durum, Türkmenler ve Türkiye’nin Irak’a Yaptığı İnsani Yardımlar", ORSAM Bölgesel Gelişmeler Değerlendirmesi, No. 13, Ekim 2014, s.2-6.

63 Henri J.Barkey, “Turkey's New Engagement in Iraq: Embracing Iraqi Kurdistan”, USIP Special Report, No. 237, May1s 2010; İbrahim Sirkeci, “Turkmen in Iraq and Their Flight: A Demographic Question”, ORSAM Report, No.21, Ocak 2011. 
ayrılmıştır. ${ }^{64}$ Başkan da halk tarafından seçildiği ve yürütme yetkilerinin önemli bir bölümünü elinde tuttuğu için bölgenin "yarı-başkanlık sistemi” ile yönetildiği söylenebilir. ${ }^{65}$

Kürtlerin toplumsal/siyasalhayatında çokbüyükbir rolü olan aşiretve ailebağlılıklarınıkurumsal yapılarını şekillendirme noktasında etkin olarak kullanan ve Erbil ile Süleymaniye vilayetlerinin Kürt siyasal varlığı ekseninde oluşturdukları ittifakı da yansıtan ${ }^{66} \mathrm{KDP}-\mathrm{KYB}$ koalisyonu, ${ }^{67}$ kendisini bölgede şekillenmiş olan Kürt siyasal varlığının arkasındaki dinamik güç ve Kürt ulusçuluğunun vazgeçilmez bir aktörü olarak konumlandırmıştır. Ancak bu koalisyon, KYB’nin son dönemde yaşadığı yönetimsel sorunlara ve Gorran'ın yükselişine paralel olarak ciddi bir sarsıntıya uğramıştır.

KYB’nin önemli isimlerinden biriyken istifa eden Noşirvan Mustafa tarafından kurulan Gorran (Değişim) Hareketi, KDP ve KYB'nin kontrolünde işleyen otoriter siyasal sistemi sorgulamak ve değiştirebilmek hedefiyle ortaya çıkmıştır. ${ }^{68} 2013$ seçimlerinde KYB'nin oy deposu olarak görülen Süleymaniye'de birinci parti haline gelen ve seçimlerden KDP'nin arkasında 24 sandalye ikinci olarak çıkan Gorran, ${ }^{69}$ uzun vadede KYB’nin pozisyonuna aday olduğunu açıkça göstermiştir.

\section{Ekonomik Görünüm}

Uluslararası Enerji Ajansı'na (UEA) göre Kürdistan Bölgesi'nin 4 milyar varillik bir petrol rezervi bulunmaktadır. ${ }^{70} \mathrm{Ne}$ var ki, Kürdistan Bölgesi’nin Doğal Kaynaklar Bakanı Ashti Hawrami, UEA’nın verdiği rakamın güncel durumu yansıtmadığını ve yapılan aramalar sonucu bölgenin petrol rezervinin

6411 sandalyenin 5'i Türkmenlere, 5'i Asurilere ve 1'i de Ermenilere aittir. Bkz. "The Kurdistan Parliament” Kurdistan Regional Government, http://www.krg.org/p/p.aspx?l=12\&s=030000\&r=319\&p=229\#structure_parliament (Erişim Tarihi 31 Aralık 2014); Bilgay Duman, "Irak Bölgesel Kürt Yönetimi Parlamento Seçimleri ve Hükümet Senaryoları", ORSAM, 25 Eylül 2013, http://www.orsam.org.tr/tr/yazilar_Yazdir.aspx?ID=4728 (Erişim Tarihi 1 Ocak 2015).

65 Nassous Hardi, "Maliki, Barzani Gain From Confrontation”, Al Monitor, 20 Aralık 2012, http://www.al-monitor.com/ pulse/ar/politics/2012/12/maliki-barzani-exploit-political.html (Erişim Tarihi 31 Aralık 2014); "Irak Kürdistan Bölgesel Yönetimi’nde Siyasal Gelişmeler ve Türkiye ile Iraklı Kürtler Arasındaki İlişkilerin Geleceği”, ORSAM Tutanakları, No.33, Eylül 2013, s.17-18.

66 KDP’ye destek veren aşiretler daha çok Dohuk ve Erbil'de konumlanmıştır. KYB ise bölgenin kültürel merkezi olarak görülen Süleymaniye ve çevresinden ciddi destek gören ve eğitimli kesimlere daha çok hitap eden bir partidir. Her ne kadar, son dönemde, Gorran Hareketi’nin Süleymaniye’deki seçim başarıları ile bölgede gücünü yitirmeye başlamış gibi görünse de güvenlikçi eğilimler ekseninde kurgulanmış ve parlamentodaki tüm siyasal grupların temsil edildiği bölgesel hükümet içerisindeki rolü KYB'yi ayakta tutmaya devam etmektedir. Bkz. Fatih Demircioğlu, “Amerikan İşgali Sonrası Kuzey Irak'ta Demokratikleşme Bağlamında Goran Hareketi”, Dicle Üniversitesi İktisadi ve İdari Bilimler Fakültesi Dergisi, Cilt 4, No.7, 2014, s. 49-59; Zana Baykal, "2014 Kürdistan Bölgesi Vilayet Seçimleri”, ORMER Perspektif Serileri, No. 2, Haziran 2014.

672013 yılındaki parlamento seçimlerine "Kürdistan Listesi” adıyla birlikte girmişler ve KDP 38, KYB ise yaşadığı güç kaybına paralel olarak 18 sandalye kazanmıştır. Michael Tanchum, "Between Ankara and Tehran: How the Scramble for Kurdistan Can Reshape Regional Relations”, Strategic Assessment, Cilt 17, No.3, Ekim 2014, s. 68-70; "Members of the Kurdistan Parliament”, The Kurdistan Parliament, http://www.krg.org/p/p.aspx?l=12\&p=229\#elections_parliament (Erişim Tarihi 1 Ocak 2015).

68 Bilgay Duman, "Irak Kürt Bölgesinde Yasemin Kokusu”, Ortadoğu Analiz, Cilt 3, No. 27, 2011, s. 38-44; Ali Semin, “Kuzay Irak’ta Goran Hareketi ve KDP-KYB İle Denge Arayışları”, BİLGESAM, 19 Haziran 2014, http:// www.bilgesam. org/incele/1620/-kuzey-irak--8217-ta-goran-hareketi-ve-kdp-kyb-ile-denge-arayislari/\#.VKWDCdKsURE, (Erişim Tarihi 1 Ocak 2015); "An Interview With Dr. Mohamed Ali, Researcher at a Research Center Affiliated to Goran Movement and Faculty Member at University of Sulaymaniyah”, ORSAM Guest, 21 Eylül 2013, http://www.orsam.org. tr/en/showOrsamGuest.aspx?ID=461, (Erişim Tarihi 22 Kasım 2014).

69 "Kuzey Irak Seçimlerinde Barzani Çıktı, Sürprizi Goran Yaptı”, T24, 23 Eylül 2013, http://t24.com.tr/haber/irak-kurtbolgesi-secimlerinde-barzani-onde,240282, (Erişim Tarihi 22 Kasım 2014); "Members of the Kurdistan Parliament", The Kurdistan Parliament, http://www.krg.org/p/p.aspx?l=12\&p=229, (Erişim Tarihi 23 Kasım 2014).

70 “Iraq Energy Outlook", IEA, Kasim 2012, http://www.iea.org/publications/freepublications/publication/ WEO_2012_Iraq_Energy_Outlook-1.pdf, (Erişim Tarihi 23 Nisan 2014); Anthony H. Cordesman ve Sam Khazai, Iraq in Crisis, Washington, Rowman\&Littlefield Publishing, 2014, s.328. 
45 milyar doları bulduğunu kaydetmektedir. Bu rakama, IŞi̇’in Musul ve çevresini işgali esnasında güvenlik kaygılarıyla Kürdistan Bölgesi tarafından kontrol altına alınan Kerkük'ün rezervleri de dâhil edilmektedir. ${ }^{71}$ Kerkük'ün 10 milyar varillik bir petrol rezervinin olduğu belirtilmektedir. Kerkük dâhil edildiğinde, bölgesel yönetimin kontrolünde bulunan topraklardaki doğalgaz rezervlerinin ise 100-200 tcm aralığında olduğu söylenmektedir. Bugün itibarılla bölgedeki petrol ve doğalgaz üretimi istatistiklerini değerlendirdiğimizde, günlük petrol üretiminin 300-400 bin varil arasında değiştiğini ve 2015 hedefinin günlük 1 milyon varil olarak ifade edildiğini görüyoruz. ${ }^{72}$

Bölgesel yönetim, ekonomik anlamda refaha kavuşabilmek ve halkın otoriter bir görünüm arz eden mevcut siyasal yapıya ilişkin değişim talebini baskılayabilmek için elinde bulunan petrol ve doğalgaz rezervlerini etkin bir şekilde kullanması gerektiğinin bilincindedir. Nitekim sanayileşme düzeyi ve üretim altyapısı anlamında bölgenin oldukça geri kalmış bir görünüm arz ettiği ve ancak enerji üretiminden elde edilebilecek gelire dayalı olarak belli sanayi kollarının geliştirilebileceği ortadadır. Kürdistan Bölgesi, bir kısmı ABD, İngiltere, Fransa ve Türkiye ${ }^{73}$ merkezli olmak üzere çok sayıda enerji şirketi ile çalışmalar yürütmektedir. ${ }^{74}$ Kürdistan Bölgesi topraklarında çıkarılan petrol hem Kerkük-Yumurtalık Boru Hattı aracılığıyla ve hem de karayolu aracılığıyla Türkiye’ye gönderilmekte ve buradan uluslararası piyasaya sunulmaktadır. Hatta Kürdistan Bölgesi topraklarından Türkiye’ye gelecek, bölgesel yönetimin yaptığı kontratlar gereği aktarılacak olan petrol/doğalgazı taşıyacak yeni petrol ve doğalgaz hatları yapımı hususu da değerlendirilmektedir. ${ }^{75}$

Bağdat ile Erbil arasında, Irak Anayasası́nın petrol ve doğalgaz üretimine/pazarlanmasına ilişkin hususların farklı şekillerde algılanmasından doğan ve Erbil'in birçok enerji şirketi ile tek taraflı anlaşmalar yapıp uygulaması ile tırmanan gerginlik tam anlamıla çözümlenebilmiş değildir. Hatta Kerkük ve çevresinin de Erbil'in denetimi altına girmesi ve bölgedeki enerji rezervlerinin de Kürdistan Bölgesi tarafından sahiplenilmeye başlanması sorunu tırmandırma ihtimali olan bir gelişme olmuştur. Erbil, 2005

71 “Ashti Hawrami Talks About 45 Million Barrels of Oil Reserves in Iraqi Kurdistan”, Ekurd Daily, 11 Temmuz 2013, http://ekurd.net/mismas/articles/misc2013/7/state7208.htm, (Erişim Tarihi 23 Aralık 2014); Veysel Ayhan, Aziz Barzani ve Hakan Demir, "Enerji Siyaseti, Türkiye-Irak Kürdistan Bölgesel Yönetimi: Boru Hatları, Petrol Satışı ve Bağdat'in Pozisyonu”, IMPR Rapor, Kasım 2013, s.13.

72 Petrol üretiminin \%4’ü Khor Mor ve ChemChemal gaz sahalarından, \%36’sı Taq Taq sahasından, \%29'u Tawqe'den ve \%31'i de Khurmala bölgesinden elde edilmektedir. Barda Rash sahasında üretim ise yeni başlamıştır. Khor Mor ve ChemChemal sahalarından doğalgaz da çıarılmaktadır ve bu gaz Baria ve Erbil elektrik santrallerinde iç tüketime yönelik olarak kullanılmaktadır. Erbil Hükümeti, önümüzdeki dönemde yeni üretime açtığı Shaikan, AkriBijeel, Sheikh Adi, BerBahr sahalarından ise günlük 150 bin varilin üzerinde bir petrol çıkarmayı hedef olarak koymuş durumdadır. Nitekim bölgeye yatırım yapan Türk şirketi Genel Enerji, sadece Taq Taq ve Tawke sahalarındaki üretimi arttırıp 200 bin varile ulaşmayı hedeflemektedir. Bkz. Ayhan, Barzani ve Demir, "Enerji Siyaseti”, s. 13.

73 Kürdistan Bölgesi ile Türkiye arasındaki enerji işbirliğini yansıtan en önemli husus, Genel Enerji (Ber Bahr sahasında \%40, Dohuk sahasında \%40, Miran sahasında \%18,75), Petoil (Bina Bawi sahasında \%23, Pulkhana sahasında \%20, Shakal sahasında \%9 ve Chia Surkh sahasında \%20) ve Doğan Enerji (Khalakan sahasında \%80), Petroquest-Çalık Enerji (Sulevani sahasında \%80, Central Dohuk sahasında \%30) gibi Türk şirketlerinin Kürdistan Bölgesi’nde elde ettiği enerji imtiyazlarıdır. Detaylı bilgi için bkz. Hakan Demir, "Irak’ta Petrol Mücadelesi: Çok Uluslu Şirketler, Uluslararası Anlaşmalar ve Anayasal Tartışmaların Işığında Bir Analiz”, ORSAM Rapor, No. 103, Ocak 2012, s.11.

$74 \mathrm{Bu}$ ülkelerin yanı sıra Hindistan, Kanada, Macaristan, Çin, Rusya, Güney Kore, Avusturya, Norveç ve Avustralya başta olmak üzere 22 farklı ülkeden 50 enerji şirketinin toplam 15 milyar dolarlık yatırım yapma taahhüdünde bulunduğu Kürdistan Bölgesi başbakanı Neçirvan Barzani tarafından ifade edilmiştir. Bkz. "Prime Minister Barzani’s Speech in the Reichstag Building”, Kurdistan Regional Government, 21 Mart 2013, http://www.krg.org/a/d. aspx? $=010000 \& \mathrm{l}=12 \& \mathrm{a}=47001$, (Erişim Tarihi 1 Ocak 2015).

75 Kerkük-Yumurtalık hattına paralel yeni bir hattın inşa edilmesi fikri hem Kürdistan Bölgesi hükümetinin hem de Federal hükümetin gelecek planları arasında yer almaktadır. Kürdistan Bölgesi Yönetimi, bu hattın kapasitesinin arttırılmasının yanı sıra özellikle doğalgaz boru hattı üzerinde durmaktadır. Ayhan, Barzani ve Demir, "Enerji Siyaseti...”, s. 14; "Kuzey Irak'ta TPIC Bir Yatırım”, Hürriyet, 16 Mayıs 2013, http://www.hurriyet.com.tr/ekonomi/23293510.asp, (Erişim Tarihi 22 Aralık 2014). 
tarihli Irak Anayasası́na göre, bölgedeki eski kaynakların Bağdat ile ortaklaşa işletileceğini, ancak yeni keşfedilen/keşfedilecek rezervlerden elde edilecek gelirin ise sadece kendisine ait olduğunu belirtmektedir. Bağdat ise bölgesel yönetimin kendisinden izin almadan diğer ülkelerle ya da şirketlerle enerji anlaşmaları imzalayamayacağını ve bu anlaşmaların geçersiz olacağını ifade etmektedir. ${ }^{76}$ Bağdat, daha da ileri giderek, Erbil ile enerji anlaşması yapan ülkeleri kendisine yönelik bir tehdit olarak algılayacağını ve şirketleri de "kara listeye" alarakülkenin geri kalan bölgelerinde buşirketlerin işyapmasına izin vermeyeceğini vurgulamaktadır. Bu husus, Kürdistan Bölgesi ile Bağdat'ın itirazlarına karşın enerji alanında işbirliği yapan Türkiye’yi de zorlayan bir gelişme olmuştur. Federal hükümet, Türkiye'yi cezalandırabilmek için Türk şirketlerinin Irak'in diğer bölgelerinde elde ettiği imtiyazları iptal edebileceğini belirtmiş ve Ankara ile Bağdat arasında karşlıklı suçlamalar ile tırmanan bir gerginlik de yaşanmıştır. ${ }^{77}$ Bu gerginlik esnasında, ABD, Ankara ile Erbil arasında Bağdat'ın izni olmadan yapılan enerji işbirliğine karşı olduğunu izlediği tutum ile yansıtmıştır. ${ }^{78}$ Zira ABD, bu işbirliğinin federal hükümeti güçsüz düşüreceğini, otoritesini sarsacağını ve Araplar ile Kürtler arasındaki gerginliği tırmandırıp yeni ve büyük bir iç savaşa yol açabileceğini düşünmüştür. Esasen bu yönde emareler de görülmüştür, ${ }^{79}$ ancak özellikle IŞİD tehdidi nedeniyle gerginlik çok uzun sürmemiştir. Irak'ta yaşanan hükümet değişikliği sonrası, ${ }^{80}$ Kasım 2014’te Türkiye Başbakanı́nın Irak’a düzenlediği ziyaret esnasında Türkiye ile Irak’ın enerji alanında işbirliğini arttıracaklarını açklamaları, Kürdistan Bölgesi’nin de bu işbirliğinin önemli bir parçası olabileceğine yönelik beklentileri arttırmışır. ${ }^{81}$

\section{Rantçı Devlet Yaklaşımı Bağlamında Kürdistan Bölgesi’ndeki İşleyişin Anlamlandırılması}

Ekonomik faktörlerin (altyapı), siyasal hayatı (üstyapı) şekillendirdiği ön kabulünden hareketle Kürdistan Bölgesi’ni değerlendirdiğimizde, bölge topraklarından çıkarılan ve çıkarılması planlanan enerji kaynaklarından (petrol ve doğalgaz) elde edilecek rant gelirinin, bölgenin toplumsal/siyasal görünümünü ve geleceğini şekillendirecek esas unsur olduğu rahatlıkla söylenebilir. ${ }^{82} \mathrm{Bu}$ bağlamda, bölgenin, Mahdavy ile Luciani ve Beblawi tarafından rantçı devlet yaklaşımı ekseninde özellikle altı çizilen Ortadoğu topraklarında yer aldığı da göz önünde bulundurulmalıdır.

76 "Irak Anayasası", ORSAM, http://www.orsam.org.tr/tr/trUploads/Yazilar/Dosyalar/20101224_irakanayasasi.pdf, (Erişim Tarihi 2 Ocak 2015); Hasan Şahin, "Irak Kürt Bölgesel Yönetimi ve Enerji”, Süreç Analiz, 22 Temmuz 2013, http://www.surecanaliz.org/makale/irak-kurt-bolgesel-yonetimi-ve-enerji, (Erişim Tarihi 2 Ocak 2015).

77 “Kürt Petrol Projesi, Türk Şirketleri Zora Sokar”, BBC Türkçe, 14 Kasım 2012, http://www.bbc.co.uk/turkce/ haberler/2012/11/121114_turkey_iraq_shahristani_kurdish_oil.shtml, (Erişim Tarihi 20 Kasım 2014).

78 “Analiz: Türkiye’ye Akan Kuzey Irak Petrolü Kimi Neden Rahatsız Ediyor?”, Enerji Enstitüsü, 9 Haziran 2014, http:// enerjienstitusu.com/2014/06/09/analiz-turkiyeye-akan-kuzey-irak-petrolu-kimi-neden-rahatsiz-ediyor, (Erişim Tarihi 21 Kasım 2014); Craig Bonfield, “Turkish-Kurdish Energy Cooperation in the Iraqi Conundrum”, CSIS, 19 Haziran 2014, http://csis.org/files/publication/140619_Kurdish.pdf, (Erişim Tarihi 22 Kasım 2014).

79 Shak Bernard Hanish, “The Current Kurdish Iraqi Governments Relations: An Evaluation”, Journal of International Relations and Foreign Policy, Cilt 1, No.2, Aralık 2013, s.1-9.

80 Mohamed Madi, “Haider al-Abadi: A New Era For Iraq?”, BBC News, 9 Eylül 2014, http://www.bbc.com/news/worldmiddle-east-28748366, (Erişim Tarihi 22 Aralık 2014).

81 Nitekim bu ziyaretin ardından Bağdat ile Erbil arasında petrol ihracatı hususunda bir anlaşmaya varılmıştır. Irak Ekonomi Bakanı Hoşyar Zebari tarafından yapılan açıklamaya göre, günde 300 bin varil petrolün Kerkük'ten, 250 bin varil petrolün ise Bölgesel Kürt Yönetimi’nin kontrolündeki diğer sahalardan Türkiye’ye gönderileceğini açıklamıştır. $\mathrm{Bu}$ anlaşmaya göre, Irak merkezi yönetimi bütçesinin \%17'sinin Kürdistan Bölgesi’ne tahsis edileceğini belirtilmiş ve Bağdat'ın, IŞĩD ile mücadele eden Erbil'e 1 milyar dolarlık bir yardımda bulunması da karara bağlanmıştır. Böylece Bağdat ile Erbil arasındaki enerji geliri paylaşımı ve ihracatı hususunda yaşanan anlaşmazlık Türkiye’nin de aracılığıyla biraz olsun geri plana itilmiştir. Bkz. "Bağdat ve Erbil Arasında Petrol Anlaşması”, BBC Türkçe, 2 Aralık 2014, http:// www.bbc.co.uk/turkce/haberler/2014/12/141202 irak petrol anlasma, (Erişim Tarihi 20 Aralık 2014).

82 Robin M.Mills, “Northern Iraq’s Oil Chessboard: Energy, Politics and Power”, Insight Turkey, Cilt 15, No.1, 2013, s.51-62. 
Kürdistan Bölgesi’nde siyasal işleyiş uzunca bir süre iki siyasi aktör tarafından yönlendirilmiştir. Tarihsel, toplumsal ve siyasal gelişmelerin ürünü olan bu yapının Gorran Hareketi eliyle özellikle son dönemde sorgulanmaya başlanması, iktidarı elinde bulunduran KDP-KYB koalisyonunu kendi siyasal/ yönetimsel meşruiyetini ve devamlılığını sağlayabilmek konusunda arayışlara sürüklemektedir. ${ }^{83}$

$\mathrm{Bu}$ arayış sürecinin bir parçası olarak, Haziran 2014 itibarıyla kurulan Kürdistan Bölgesi hükümetinde, KDP ve KYB’nin yanı sıra, bölgedeki siyasal değişim isteğini yansıttığı belirtilen ve 2013'te düzenlenen parlamento seçimlerinde KYB'nin önünde ikinci sırayı alan Gorran Hareketi de yer almaktadır. Hatta özellikle KDP’nin çabaları sonrası parlamentoda temsil edilen Kürdistan İslami Birliği ile Kürdistan İslami Cemaati gibi muhafazakâr partiler de hükümet içerisinde konumlanmıştır. Bunun yanı sıra, Kürdistan Bölgesi’nde yaşayan ve kendilerine tanınan kotalar itibarıyla bölgesel parlamentoda temsil edilen azınlıklara da hükümet içerisinde yer verilmiştir. ${ }^{84}$ Böylece Kürdistan Bölgesi'nde bir ulusal birlik hükümeti kurulduğu mesajı verilmeye çalışıldığı gibi, elde edilen rantın dağıtımı noktasında bu aktörlere de önemli bir pay ayrılacağı gösterilerek, KDP ve KYB ittifakına yönelen siyasal ve ekonomik tabanlı eleştiriler önlenmeye çalışılmıştır. ${ }^{85}$ Gorran Hareketi'nin ortaya çıkışı ve güç kazanması, Okruhlik'in altını çizdiği üzere rantın eşitsiz dağıtımından doğan bir toplumsal/siyasal muhalefetin Kürdistan Bölgesi'nde de belirdiğini göstermektedir. Bu çerçevede, özellikle bölgenin en güçlü partisi olan KDP’nin, Gorran başta olmak üzere mecliste temsil edilen tüm muhalif partileri ve azınlıkları da bölgesel hükümetin bir parçası haline getirerek yükselen muhalif dalgayı etkisizleştirmeye ve muhalif hareketleri de hükümetin politikalarından sorumlu tutma yönünde bir çabaya giriştiğini görüyoruz.

Rant gelirinin artması ve yönetimin, bu rantı, toplumsal hayatta etkin bir rol oynayan aşiretler üzerinden dağıtıyor olması özellikle Hazem Beblawi tarafından ortaya konan, "rant gelirinin özellikle iktidara etkin bir şekilde destek veren aşiretler, kabileler ve aileler üzerinden aktarıldığı” savına da uygun düşmektedir. Üstelik rant geliri eliyle elde edilen ekonomik, askeri, diplomatik ve siyasal atılımlar eliyle Kürt ulusçuluğuna ve toplumun büyük bir bölümü tarafından bir hedef olarak görülen/ gösterilen bağımsızlık talebine ilişkin söylemlerin uluslararası arenada dillendirilmeye başlanmış olmass ${ }^{86}$ rantın ne denli etkin bir siyasal araç olabileceğini kanıtlamaktadır.

83 Serhat Erkmen, "Key Factors For Understanding Political Dynamics in Northern Iraq: A Study of Change in the Region", Uluslararası Hukuk ve Politika, Cilt 8, No.31, 2012, s.83-102.

84 Neçirvan Barzani’nin başbakanlığında kurulan yeni hükümette, Peşmerge Bakanlığı gibi oldukça önemli bir görev Gorran Hareketi'ne verilmiştir. Bunun yanı sıra; Maliye, Ticaret ve Sanayi ile Din İşleri gibi bakanlıklar da Gorran Hareketi’nin olmuştur. Azınlık statüsünde olan Türkmenler, Sinan Çelebi aracılığıyla Adalet Bakanlığı görevini üstlenirken, Ulaştırma Bakanlığı koltuğuna da Süryani (Hiristiyan) Johnson Siyavuş oturmuştur. Bkz. "Irak’ta Yeni Kürt Hükümeti Seçimden 10 Ay Sonra Kuruldu”, Bugün, 18 Haziran 2014, http://www.bugun.com.tr/dunya/yeni-hukumet-10-ay-sonra-gorevebasladi-haberi/1150376, (Erişim Tarihi 8 Nisan 2015).

85 2013'te düzenlenen seçimlerden sonra Gorran Hareketi’nin hükümet kurma sürecinde KDP'ye yakınlaşması ve yalnızca esas rakibi olarak gördüğü KYB'yi eleştiren bir parti haline dönüşmesi, "değişim” vaadi üzerinden KDP ve KYB'yi ve bölgesel yönetimin işleyişini sorgulayan yönüyle öne çıkan Gorran'ın tabanının bir bölümünü olumsuz yönde etkilemiştir. Nitekim bu partinin KDP ile birlikte hükümet kurmaya sıcak bakması, değişim vaadinin gerçekçi olmadığına ve Gorran'ın esas amacının KYB’yi etkisizleştirmek olduğuna dair bir görünüm oluşturmuştur. Bu durum, 30 Nisan 2014'te Kürdistan Bölgesi'nde gerçekleştirilen yerel seçimlerde Gorran'ın, KDP ve KYB'ye oranla oy sayısını çok az arttırabilmesine, hatta yerel seçim sıralamasında KYB’nin arkasında üçüncü olmasına yol açmıştır.

86 Alexander Whitcomb, “Kurdistan Region's Oil and Gas: Curse or Blessing?”, Rudaw, 27 Nisan 2014, http://rudaw.net/ english/business/27042014, (Erişim Tarihi 6 Ocak 2015); Denise Natali, "Kurdistan Seems to be Following Rentier State's Path”, The Kurdistan Tribune, Aralık 2013, http://kurdistantribune.com/2013/denise-natali-kurdistan-seemsbe-following-rentier-states-path, (Erişim Tarihi 5 Ocak 2015); Luke Harding ve Fazel Hawramy, "Kurds Hope Oil Boom Will Fuel Prosperous Independent Future”, The Guardian, 14 Haziran 2014, http://www.theguardian.com/ world/2014/jul/14/kurdish-technocrats-discuss-kurdistan-oil-wealth, (Erişim Tarihi 27 Aralık 2014). 
Kürdistan Bölgesi'nin otoritesi altında yer alan topraklarda bulunan doğal kaynakların büyük bir bölümü (Kerkük ve çevresi de dahil) henüz üretime kazandırılamamış olsa da, elde edilen rant geliri sayesinde bölgede kişi başına düşen milli gelir daha şimdiden ciddi bir artış göstermiş ve 6 bin doları bulmuştur. ${ }^{87}$ Bundan 6-7 yıl önce bölgede kişi başına düşen milli gelirin 400-500 dolar civarında olduğu düşünüldüğünde rant gelirinin artması ile ne denli dramatik bir değişimin yaşandığı ortadadır. ${ }^{88}$ Elde edilen rant gelirinin toplumun geneline dengeli ve adil bir şekilde dağıtılmadığı biliniyor olsa da, önümüzdeki yıllarda enerji kaynaklarından elde edilecek satış gelirinin büyük bir atılım göstereceği, hatta sürecin olumlu ilerlemesi durumunda ${ }^{89}$ mevcut düzeyinin birkaç katına kadar ulaşabileceğine dair yorumlar da yapılmaktadır. Ancak rantın "eşitsiz" dağıtılıyor oluşu, Okruhlik’ in de belirttiği üzere, Gorran özelinde de belirginleşen toplumsal/siyasal muhalefetin her daim var olacağına yönelik bir beklenti yaratmaktadir.

Bunun yanı sıra, elde edilen rant geliri aracılığıyla devlet (bölgesel yönetim) tarıma ve hayvancılığa uyguladığı sübvansiyonları arttırmakta, halktan vergi almamayı sürdürmekte ve bürokrasi ile güvenlik (Peşmerge kuvvetleri, polis teşkilatı, vb.) alanında çok sayıda yeni iş yaratmaktadır. ${ }^{90}$ Kürdistan Bölgesi’nin, bu bağlamda, Luciani’nin ele aldığı "tahsisat devletleri”ne ya da Delacroix'in üzerinde durduğu "dağıtımcı devletler"e (bağımsız bir devlet olmamasına karşın) örnek olarak gösterilebileceği ortadadır. Bölgede, rant gelirinin artmasına paralel olarak sürekli bir artış içerisinde olan devlet kadrolarına aşiretler arasındaki dengeyi gözetmeye çalışılarak ve ailelerin/aşiretlerin yönetime verdiği destek de göz önünde bulundurularak çok sayıda kişi atanmaktadır. Daha önce PKK kadrolarında Türkiye'ye karşı savaşan eski militanlar da giderek artan bir hızla Kürdistan Bölgesi’ne entegre olmakta ve özellikle Peşmerge ve polis teşkilatında görev yapmaktadır. ${ }^{91} \mathrm{Ne}$ var ki, bu noktada ciddi bir sorunun varlığından da söz etmek gerekmektedir. Bölgede Kürtlerin ardından en fazla nüfusa sahip etnik/toplumsal grup olan ve Türkiye ile Kürdistan Bölgesi arasındaki ilişkileri de olumlu ya da olumsuz yönde etkileme kapasitesine sahip Türkmenler, ${ }^{92}$ Kürdistan Bölgesi’ne toplumsal/siyasal manada entegre olmadıkları ve bölgesel yönetim de devlet tarafından yaratılan iş olanaklarını Kürtler dışında kalan toplumsal gruplara dağıtma hususunda son derece şüpheci ve isteksiz hareket ettiği için, bölgede etnik/toplumsal farklılıklar üzerinden çıkabilecek bir çatışma ihtimali yüksektir.

87 “Irak Pazarı için Kentlerin İşbirliği Şart”, Refleks, 7 Eylül 2013, http://www.refleksgazetesi.com/mansetdevam. asp?id=2251, (Erişim Tarihi 22 Kasım 2014).

88 Nazlı Üstün, “Türkiye-Kuzey Irak İlişkileri ve Ekonomik Yansımaları”, Konya Ticaret Odası (KTO) Etüd-Araştırma Servisi, 2012, s.6.

89 Irak Hükümeti ile Kürdistan Bölgesi arasındaki siyasal otorite ve ekonomik paylaşım mücadelesinin herhangi bir toplumsal/ askeri/siyasal çatışmaya mahal vermeden kısa bir süre içerisinde sonlandırılması ve mevcut rezervlerin çıkarılıp dünya piyasasına sürülmesi noktasında uluslararası enerji şirketleri arasında herhangi bir sorunun çıkmaması önemlidir. Kürt Yönetimi altında bulunan topraklarda yaşayan Türkmenler ve Araplar gibi farklı etnik/ulusal gruplar ile egemen toplumsal grup Kürtler arasındaki ilişkilerin sorunsuz bir şekilde yürütülmesi ve Kürt aşiretleri arasında yaşanabilecek bir paylaşım rekabeti ve bunun doğuracağı çatışmanın engellenmesi önemli birer içsel faktör olarak değerlendirilmelidir. Bunun yanı sıra, Kürdistan Bölgesi ve Irak’ın Türkiye ve İran gibi komşu ülkelerle iyi ilişkiler içerisinde olması ve IŞİD tarzı terör örgütlerinin etkisizleştirilerek ortadan kaldırılması, bu anlamda üzerinde durulması gereken ve siyasal/ekonomik istikrarı doğrudan etkileyecek faktörler olarak görülmelidir. Suriye’de siyasal istikrarın sağlanması ve Türkiye’nin yaşadığı Kürt Sorununun Kürdistan Bölgesi üzerinde herhangi bir olumsuz etki yaratmadan çözümlenmesi de Kürdistan Bölgesi’nde ekonomik refahın ve dolayısıyla kişi başına düşen milli gelirin artmasını sağlayacaktır.

90 Ayad Mirza, "How to Start Up Doing Business in the Kurdistan Region?", Deloitte Kurdistan Review, http://www. investingroup.org/files/how\%20to\%20start-up\%20-\%20doing\%20business\%20in\%20kurdistan.pdf, (Erişim Tarihi 3 Ocak 2015).

91 “PKK'lllar Peşmerge Oldu”, Hürriyet, 18 Temmuz 2007, http://www.hurriyet.com.tr/gundem/6914797.asp, (Erişim Tarihi 21 Aralık 2014); “PKK’nın Eski Komutanından Peşmergeye Eğitim”, Sabah, 20 Kasım 2014, http://www.sabah. com.tr/gundem/2014/11/20/pkknin-eski-komutanindan-pesmergeye-egitim, (Erişim Tarihi 26 Kasım 2014).

92 Ali Semin, “Türkiye’nin Irak Politikası Işı̆̆ında Kuzey Irak Açılımı”, Bilge Strateji, Cilt 3, No.5, 2011, s.179-205. 
Kürdistan Bölgesi, rant gelirini üretime yönlendirme hususunda şimdiye dek isteksiz ve etkisiz kalmıştır. Hatta bölgede endüstriyel üretimin neredeyse hiç yapılmadığı bilinmektedir. ${ }^{93} \mathrm{Bu}$ durum, Mahdavy, Luciani ve Beblawi'nin bahsettiği "rantçı devletlerde üretim sürecini üstlenecek yerel bir sanayinin geliştirilemeyeceği” gerçekliği ile uyumludur. Bölgede, ranttan elde edilen gelirle Erbil ve Süleymaniye başta olmak üzere önemli şehirlerde büyük ve yüksek binalar, Batılı tarzda alışveriş merkezleri, düzgün ve geniş yollar, lüks evler ve üniversiteler inşa edilmiş, pahalı araçlar ile insanları tüketime yönlendirecek çok sayıda kaliteli markanın da bölgeye girmesi sağlanmışır. ${ }^{94}$ Hizmetler sektörü ise gelişim aşamasındadır. Bu durum, diğer rantçı devletlerde beliren ekonomik yapının neredeyse tam olarak aynısıdır. Zira bu tarz ihtişamlı binaların yapılması ve insanların tüketime yönlendirilmesi, üretim yapılmıyor olmasına karşın, bölgenin dünya ekonomisine ve modern yaşam anlayışına entegre olduğu görüntüsünü yaratmakta ve Kürtlerin bölgesel yönetime olan siyasal bağlılıklarını arttırmaktadır.

ABD’nin, Kürdistan Bölgesi topraklarında bir askeri üs oluşturarak buraya askerlerini konuşlandırmayı düşündüğü de belirtilmektedir. Erbil yakınlarında bulunan Herir Askeri Havalimanı çevresinde kurulması planlandığına dair haberler yayınlanan Amerikan askeri üssü, ${ }^{95}$ hiç kuşkusuz bölgesel yönetime ciddi bir rant geliri sağlayabilecek ya da rant gelirinin sağlanması anlamında önemli bir rolü olan bölgesel güvenliğin ön planda tutulduğunu gösteren bir gelişme olarak değerlendirilmelidir. Zira Kürdistan Bölgesi'ndeki petrol ve doğalgaz rezervleri ile yakından ilgili olan firmaların birçoğu $\mathrm{ABD}$ merkezlidir ya da ABD'nin müttefiki olan ülkelere kayıtlıdır. ${ }^{96} \mathrm{ABD}$ 'nin bölgeye asker konuşlandırması ihtimali, doğal kaynakların üretimi ve pazarlanması anlamında çok önemli olan istikrar ve güvenliğin sürdürülmesi hususunun öncelendiğini kanıtlamaktadır. Böylece hem P.W. Moore'un rantçı devletlerde iş çevreleri ve siyasal yapı (özellikle güvenlik) arasındaki etkileşimin altını çizen yaklaşımı hem de Delacroix' in dünya sistemi yaklaşımına referansla betimlediği "merkez ülkelerin ekonomik işleyişleri açısından çok önemli olan doğal kaynakları, bu kaynaklar açısından zengin olan çevre ülkeler yönetimleri ile yapacakları siyasal işbirliğine bağlı olarak ve bu yönetimlerin devamlılı̆̆ını sağlayarak korudukları” hususu Kürdistan Bölgesi özelinde açıkça gözler önüne serilmektedir.

Rantçı devlet yaklaşımının öngördügü üzere endüstriyel üretim altyapısına sahip olmayan ve elde ettiği rant gelirini tüketim ihtiyaçlarını karşılayabilmek için kullanan Kürdistan Bölgesi, büyük bir yoğunlukla Türkiye ve son dönemde artan bir hızla İran üzerinden ithalat yaparak halkın ihtiyaçlarını karşılamaya çalışmaktadır. Türkiye'den yaptığı tüketim malları ithalatını Habur sınır kapısından sürdüren ve Ankara ile yeni sınır kapıları inşa edilmesi yönünde görüşmeler yürüten Erbil, ${ }^{97}$ son dönemde

93 Derya Eğrican Güleç, “Gümrük Duvarı Örülmeden Kuzey Irak’a Yatırım Yapın”, Dünya, 31 Ocak 2013, http://www. dunya.com/gumruk-duvari-orulmeden-kuzey-iraka-yatirim-yapin-180037h.htm, (Erişim Tarihi 22 Kasım 2014).

94 Erbil'e 25 km mesafede yer alan ve Kürdistan Bölgesi Başkanı Mesud Barzani, KDP’nin üst düzey yetkilileri ile zengin işadamlarının konakladığı Selahaddin kasabasındaki lüks binalar ve gelişmiş altyapı hizmetleri ile Erbil’i Süleymaniye, Dohuk ve Türkiye'ye bağlayan karayollarının kalitesinin sürekli bir gelişim içerisinde olması, bölgede sayısı gittikçe artan Hummer, Land Cruiser ve Mercedes marka araçlar ile birlikte ele alındığında, rant gelirinin bölgede yarattığı zenginlik ve refah artışı gözler önüne serilmektedir. Ne var ki, rant gelirinin dağıtımı konusunda aşiretler, aileler ve şehirler/kasabalar anlamında ciddi bir eşitsizliğin olduğu da ifade edilen bir gerçekliktir. Bkz. Haşim Söylemez, "Kürdistan Sarhoşluğundan Geçim Derdine Kuzey Irak”, Aksiyon, Kasım 2007, http://www.aksiyon.com.tr/aksiyon/newsDetail_openPrintPage. action?newsId=16672, (Erişim Tarihi 21 Kasım 2014).

95 “US to Take Airport in Iraq's Kurdistan As Military Base: Officials”, Press TV, 23 Ekim 2014, http://www.presstv.ir/ detail/2014/10/23/383335/us-to-take-iraq-airport-as-military-base, (Erişim Tarihi 26 Ekim 2014).

96 "List of Oil Companies in Kurdistan", Iraq Business News, 25 Haziran 2013, http://www.iraq-businessnews. com/2013/06/25/list-of-oil-companies-in-kurdistan, (Erişim Tarihi 1 Kasım 2014).

97 “Habur’a Ek 4 Yeni Sınır Kapısı”, Rudaw, 24 Eylül 2014, http://rudaw.net/turkish/business/240920141, (Erişim Tarihi 1 Aralık 2014). 
İran'dan, Hacı Ümran sınır kapısı üzerinden de ithalatını arttırmıştır. ${ }^{98}$ Beblawi ve Luciani’nin altını çizdiği doğal kaynak paylaşım antlaşmaları konusunda Irak merkezi hükümetinin daha önce yaptı̆̆ı antlaşmaların yanı sıra, son dönemde kendisi de birçok enerji şirketi ve ülkeyle bu tarz antlaşmalara imza atan Erbil Hükümeti, anayasal anlamda federe bir devlet olduğu ve Irak Anayasası́nın işleyişine ilişkin olarak Bağdat ile otorite paylaşımı hususunda sorunlar yaşadı̆̆ı için, kendisine rant sürekliliği sağlayacak paylaşım antlaşmaları konusunda, çözülmesi gereken meselelerle karşı karşıyadır. Bu husus aynı zamanda, Chaudhry tarafından altı çizilen ve içsel faktörlerin de rantın elde edilmesi sürecinde olumsuz etkileri olabileceğini gösteren bir gerçekliktir. Bu nedenle, Erbil’in siyasal gerekçelerle de facto olarak uygulama alanına koyduğu paylaşım antlaşmalarını de jure bir statüye kavuşturması gerekmektedir.

Hükümetin en önemli işveren konumunda olduğu Kürdistan Bölgesi’nde işsizlik halen önemli bir problem olarak görülmektedir. ${ }^{99}$ Bölgeye ilişkin bir araştırma yapılmamış olmasına karşın, IŞ่̇D’in Musul'u işgalinin ardından yapılan bir incelemede, Irak genelinde işsizlik oranının \%20'yi aştığı ve gençler arasındaki işsizlik oranının ise $\% 38$ 'i bulduğu değerlendirmesi yapılmıştır. ${ }^{100}$ Elde edilen rant gelirinin daha düzenli bir şekilde kamu harcamalarına çevrildiği ve yönetimin bölgede yaşanabilecek toplumsal/siyasal huzursuzluğu ortadan kaldırabilmek ya da azaltabilmek için ciddi bir çaba içerisinde olduğu Kürdistan Bölgesi’nde ise işsizlik oranlarının normal şartlarda Irak geneline oranla daha düşük olması beklenmelidir. Ne var ki, son dönemde 150 binden fazla Suriyeli Kürt ile Irak'in diğer bölgelerinden gelen 300 bin civarında Iraklı’nın Kürdistan Bölgesi’ne sığınması bölgedeki fiili nüfusun ciddi oranda artmasına neden olmuştur. ${ }^{101}$ Gelen kişilerin önemli oranda niteliksiz işgücü oluşturduğu da dikkate alındığında Kürdistan Bölgesi’nde işsizliğin önemli bir problem olduğu söylenebilir. Bölgede işsizliğin arkasında yatan en önemli neden ise, bölge nüfusunun önemli bir bölümünün genç olması ve bu gençlerin eğitim seviyelerinin çok yüksek olmamasının yanı sıra, onların kaliteli bir şekilde öğretim görebilecekleri yeterli bir okullaşma düzeyine ulaşılamamış olmasıdır. Bölgesel yönetim, son dönemde, artan rant gelirlerini okul ve üniversite yatırımlarına dönüştürmeye çalışıyor olsa da, bunun etkisi ancak uzun vadede görülebilecektir. ${ }^{102}$ Nitekim rantın elde edildiği ve çoğunlukla uluslararası enerji şirketlerinin çalışanı olan yabancı mühendis ve işçilerin istihdam edildiği petrol endüstrisi dışında bölge nüfusunun çok büyük bir bölümü rant gelirine dayalı olarak hayatını sürdürmekte, devlet bürokrasisi ve güvenlik birimlerinde çalışanların yanı sıra, nüfusun önemli bir bölümü de tarımhayvancılık ve özellikle transit ticaret ile uğraşmaktadır. Bu görünüm, Beblawi ve Luciani’nin altını çizdiği ve "çalışan nüfusun ancak çok küçük bir bölümünün rant elde edilmesi sürecine dahil olduğu ve nüfusun çok büyük bir bölümünün dağıtılan ranttan faydalandığı” görüşünün Kürdistan Bölgesi açısından da geçerli olduğunu göstermektedir.

Kürdistan Bölgesi’nin, Luciani’nin üzerinde durduğu “tahsisat devletleri”ne örnek olarak gösterilebilecek bir görünüme sahip olduğu söylenebilir. ${ }^{103}$ Nitekim yönetimin gelirinin neredeyse

98 "Local Authorities Aim to Expand Border Crossings With Iran Due to Trade Increase", Rudaw, 6 May1s 2014, http:// rudaw.net/english/business/06052014, (Erişim Tarihi 1 Aralık 2014).

99 “Unemployment Increases in Kurdistan Region”, Iraq Business News, 12 Eylül 2014, http://www.iraq-businessnews. com/tag/unemployment, (Erişim Tarihi 22 Kasım 2014).

100 Ali Semin, “Irak’ta Derinleşen IŞiD Krizi ve Türkmenler”, BİLGESAM, 21 Ağustos 2014, http://www.bilgesam.org/ incele/1750/-irak\%E2\%80\%99ta-derinlesen-isid-krizi-ve-turkmenler/\#.VK0-KdKsWE0, (Erişim Tarihi 20 Aralık 2014).

101 “BM: Suriyeli Kürtler Kuzey Irak’a Göç Ediyor”, BBC Türkçe, 18 Ağustos 2013, http://www.bbc.co.uk/turkce/ haberler/2013/08/130818_unhcr_suriye_irak, (Erişim Tarihi 8 Nisan 2015).

102 “Overview: Kurdistan Region of Iraq, Education”, Invest Group, http://www.investingroup.org/publications/kurdistan/ overview/education, (Erişim Tarihi 18 Kasım 2014).

103 Luciani, “Allocation vs.", s.65-84. 
tamamı petrol/doğalgaz rezervlerinden elde edilen rant üzerinden kurgulanırken, rant gelirinin kesilmesi, ciddi bir azalış göstermesi ya da fiyatında yaşanabilecek dramatik bir düşüş halinde, kendi kendisine yetecek bir endüstriyel ya da tarımsal üretim anlayışına ya da kapasitesine yaslanmayan bölgesel yönetimin siyasal olarak ayakta kalması ve sıklıkla dillendirdiği bağımsızlık söylemini devam ettirmesi de mümkün olmayacaktır. Zira rant gelirinin olmaması ya da azalması halinde özellikle son dönemde başlatılmış olan imar projeleri (toplu konut ve alışveriş merkezi yatırımları, üniversiteler, yollar, vb. ${ }^{104}$ giderek artan sosyal yardımlar, tüketimi özendiren ticari uygulamalar ve yürürlüğe konması planlanan kalkınma hamlelerine (yerli bir endüstriyel üretim yaratma hedefi) aktarılacak kaynak azalacak ya da tamamen durdurulabilecektir. Rant gelirinde yaşanabilecek bir azalma veya orta/ uzun vadede kişi başına düşen gelirin artmaması ve adil paylaşım hususunda ileri bir adım atılmaması durumlarında dahi Kürt ulusçuluğuna yaslanan otoriter siyasal söylemin/yapının toplumsal/siyasal meşruiyetinin ortadan kalkma ihtimalinin olduğu ortadadır.

Kürdistan Bölgesi’nde siyasal işleyişin ve aktörlerin uzun zamandır değişmiyor olmasının en önemli nedenlerinden biri de üretime yönlendirilmeyen, Irak geneline oranla nisbi bir güvenlik ortamı içerisinde vergi dahi vermeden devletin yarattığı iş imkânlarından faydalanan ve sübvansiyonlara dayalı bir yaşam süren nüfusun çoğunluğunun, yaşanabilecek bir siyasal değişim sonrasında bu imkânlardan faydalanma açısından sorun yaşayabileceğini düşünüyor olmasıdır. Uzun yıllar boyunca Bağdat ile siyasal/yönetimsel özerklik elde edebilmek için çatışan, büyük çaplı katliamlara ve insanlık trajedilerine sahne olan ve Irak-İan Savaşı ile I. Körfez krizinde açlı̆̆ın ve yoksulluğun ne olduğunu tecrübe etmiş bir toplumun, bugün gelinen noktadan hoşnut olmaması mümkün değildir. Bu bağlamda, siyasal değişim talebine bağlı olarak yaşanabilecek bir toplumsal/siyasal anlaşmazlık ve çatışmaya paralel olarak, elde edilmiş ekonomik ve siyasal kazanımların da kaybedilebileceği çekincesi, şimdi hükümet ortağı da olan Gorran Hareketi dışında siyasal yapıya ciddi bir itirazın belirmesini zorlaştırmaktadır. $\mathrm{Bu}$ çerçevede, Jill Crystal'in, ekonomik kazançlarda kaydedilecek dramatik bir artışın siyasal hareketliliği zayıflatacağı ve değişim talebinin önünü tıkayabileceğine dair analizi, Kürdistan Bölgesi bağlamında karşlık bulmaktadır.

Kürdistan Bölgesi hükümeti, kendisine destek veren kişi, grup ya da aşiret/ailelere rantın önemli bir bölümünü dağıtarak, onları bürokrasinin ve Peşmerge kuvvetleri başta olmak üzere güvenlik unsurlarının üst düzey pozisyonlarına getirerek, kendi pozisyonunu onlar açısından meşru hale getirmeye çalışmaktadır. ${ }^{105} \mathrm{Bu}$ nedenle, Kürdistan Bölgesi’nde kurgulanan bürokrasinin ve güvenlik teşkilatının neredeyse tamamının, mevcut iktidara tamamıyla bağımlı ve sadık insanlardan, gruplardan müteşekkil olduğunu söylemeliyiz. ${ }^{106}$ Bu gerçeklik, P.W.Moore’un, iş çevreleriile yönetici elit arasındaki ittifakın oluşturulduğu hallerde iktidarın dağıtımcı rolünün daha etkin bir şekilde yürütülebileceğine dair analizine de uygundur. Endüstriyel ve tarımsal üretim hususundaki dışsal bağımlılığın altı sürekli olarak çiziliyor olsa da, rantçı devletlere özgü bir uygulama olan vergi uygulamasının yapılmaması ${ }^{107}$ ve

104 Denise Natali, Kurdish Quasi-State: Development and Dependency in Post Gulf-War Iraq, New York, Syracuse University Press, 2010, s. 95-107.

105 Kürdistan Bölgesi topraklarında yaşayan belli başlı Kürt aşiretleri olan Ako, Balaktyan, Barzan, Bradost, Dizayi, Doski, Guti, Mizuri, Reykani, Sindi, Surçi, Suleyvani, Selefani ve Zebari gibi aşiretlerin çok büyük bir bölümü mevcut iktidara destek vererek rant dağıtımı aşamasında kendi payına düşen kısmı almaktadır. Bazıları ise kendi aralarında bölünmelere uğramıştır. Ne var ki, bu bölünmeler daha çok KDP ve KYB’ye ayrı ayrı verilecek destek noktasında belirmektedir. Gorran ve PKK çizgisine yakın Kürdistan Demokratik Çözüm Partisi'ne verilen destek ise geleneksel aşiret bağlantılarından azade bir görünüm sergilemektedir. Bkz. Erkmen, "Key Factors”, s.91-94; Demircioğlu, "Amerikan İşgali Sonrası", s.57.

106 Triska Hamid, "Corruption and Cronyism Hinder Kurdistan”, Financial Times, 5 Eylül 2012, http://www.ft.com/intl/ cms/s/0/ea716668-f759-11e1-8c9d-00144feabdc0.html\#axzz3O9F9zuFR, (Erişim Tarihi 17 Kasım 2014).

107 Kürdistan Bölgesi hükümeti, vatandaşlarına neredeyse hiç vergi uygulamamaktadır. Yani vatandaşlarından gelir elde 
adaletsiz paylaşım hususundaki itirazlara karşın, kişi başı gelirde dramatik bir artışın yaşanıyor olması, toplumun siyasal sistemi sorgulamaya yönelik bir girişimde bulunmasını engellediği ya da ertelediği gibi, siyasal katılım talebi de ciddi anlamda baskılanabilmektedir. ${ }^{108}$ Bölgede siyasal katılım hususunda göze çarpan en önemli faktör, rant dağıtımında da olduğu üzere, aşiret liderlerinin ya da onların belirlediği isimlerin parlamentoda ve hükümette etkin bir pozisyonda olmalarıdır. ${ }^{109}$ Uygulanacak ekonomi politikalarının Erbil'deki hükümet tarafından tespit edilmesi, ihalelerin ve ticari lisans izinlerinin iktidarda bulunan ya da iktidara yakın aşiretlere dağıtılması ve devlet kadrolarının dağıtımı aşamasında nepotizmin ileri seviyelere vardırılmış olması Kürdistan Bölgesi’nin rantçı devlet karakteri taşıdığını gösteren önemli birer örnektir. Ancak nepotizm bağlamında değerlendirilebilecek bu yapı toplumun önemli bir kesimini yönetimden ve siyasal katılımdan soyutlamakta ve ileride tehlike yaratabilecek bir toplumsal/siyasal yabancılaşmaya neden olmaktadır. Gorran'ın yanı sıra, PKK'nın Kuzey Irak'taki kolu Kürdistan Demokratik Çözüm Partisi ve hatta İslami duyarlılıkları ön plana süren siyasi partiler (Kürdistan İslami Birliği, Kürdistan İslami Cemaati, vb.) uzun vadede bu durumdan yararlanarak etkinliklerini daha da arttırabilir.

Bağımsızlık talebini dillendirmeye başlamış olan Kürdistan Bölgesi, neredeyse hiç sanayi üretimine sahip olmaması ve temel tüketim malları hususunda tamamıyla komşu ülkelere muhtaç olması hasebiyle, bağımsızlık söyleminin içini boşaltacak bir ekonomik bağımlılık ilişkisi içerisindedir. ${ }^{110}$ Bölgeye yatırım yapmış olan ülkelerin ve şirketlerin ekonomik durumu da Kürdistan Bölgesi’nin ayakta kalmasını sağlayan rant gelirinin oluşumuna doğrudan etki ettiği için, Erbil’i doğrudan ilgilendiren bir husustur. Yani hem rant gelirinin yaratılması hem de yaratılan gelirin tüketim ihtiyacına yönelik olarak kullanılması aşamasında Erbil’in çift yönlü bir bağımlılık ilişkisi içerisinde olduğu söylenebilir.

Rantçı devletlerde, halkın refah seviyesinin ve devlet/kamu harcamalarının arttırılması ile çoğulcu bir siyasal yaşam anlayışı/beklentisi arasındaki olumsuz korelasyonu yansıtan örneklerden biri de, görüldüğü gibi, Kürdistan Bölgesi'dir. Nitekim mevcut iktidar, devlet bürokrasisi ve güvenlik birimlerine yoğun bir şekilde eleman alımı yaparak, tüketimi teşvik ederek ve insanları çok daha kolay etkileme kapasitesine sahip büyük çaplı imar yatırımları yaparak, otoriter kalıplara yaslanan siyasal anlayışının sorgulanmasını engellemeye çalışmaktadır. Özellikle medya üzerine uygulanan baskı ve sindirme girişimleri de bu çabanın önemli bir parçasını oluşturmaktadır. ${ }^{111}$

etme gibi bir anlayışa sahip değildir. Daha önce su ve elektrik kullanımı üzerinden dahi vergi talebinde bulunmayan Erbil yönetimi, bugün bu kalemlere çok cüzi (sembolik) bir vergi getirmiş durumdadır. Esnaflar ve ticaretle uğraşanlar ise vergi ödememektedir. Bkz. Burhan Ekinci, “Devlet Olmayan Devlet”, Al Jazeera Turk Dergi, 15 Ekim 2014, http:// dergi.aljazeera.com.tr/2014/10/15/devlet-olmayan-devlet-kurdistan, (Erişim Tarihi 18 Kasım 2014).

108 Kişi başına düşen yıllık gelir 6-7 bin dolar civarında hesaplansa da, gelir dağılımındaki adaletsizlikten dolayı rant geliri daha çok zengin azınlığın cebine girmektedir. Yani zengin-fakir uçurumu oldukça derindir ve bu derinlik sürekli olarak tahkim edilmektedir. Bu durum, özellikle son dönemde ciddi bir rahatsızlık da yaratmaya başlamıştır. Gorran'ın siyasal varlığı ve toplumsal desteği neredeyse tamamen bu söylemin üzerine temellendirilmiştir. Rantçı devletlerde, genel olarak, yapılan devlet harcamalarını denetleyecek sivil ve şeffaf bir otorite bulunmamaktadır. Bugün bölgede en popüler meslek haline gelmiş olan peşmergenin aylık geliri 500-700 dolardır. Alt düzey bir bürokrat (devlet memuru) ise ancak 400-500 dolar arasında bir aylık gelire sahiptir. Bkz. "Irak Ordusundan Ayrılan Kürt Askerler, Peşmerge Ordusuna Alınıor”, Zaman, 22 Temmuz 2014, http://www.zaman.com.tr/dunya_irak-ordusundan-ayrilan-kurt-askerlerpesmerge-ordusuna-aliniyor_2232951.html, (Erişim Tarihi 6 Aralık 2014).

109 Örneğin Barzan aşiretinden gelen Mesud Barzani başkanlık, Neçirvan Barzani ise başbakanlık koltuğunda oturmaktadır. Bunun yanı sıra, Zebari aşiretinden olan Hoşyar Zebari Irak hükümetinde Maliye Bakanlığı yapmaktadır. Dizayi aşiretinden olan Sefin Dizayi ise Kürdistan Bölgesi Hükümet Sözcülüğü görevini yürütmektedir.

110 Bkz. Natali, The Kurdish Quasi-State.

111 "Iraqi Kurdistan: Growing Effort to Silence Media”, Human Rights Watch (HRW), 24 Mayıs 2011, http://www.hrw.org/ news/2011/05/24/iraqi-kurdistan-growing-effort-silence-media, (Erişim Tarihi 11 Kasım 2014). 


\section{Sonuç}

Hüseyin Mahdavy tarafından tek bir doğal kaynak/emtia üzerinden gelir elde eden ülkelere referansla ortaya konmuş olan ve başta Jacques Delacroix Giacomo Luciani, Hazem Al Beblawi, Jill Crystal, Kiren Chaudhry, Gwenn Okruhlik ve Pete W. Moore gibi isimler tarafından kuramsal düzeyde çeşitli eklemeler ve tespitler ile geliştirilen rantçı (rantiyeci) devlet yaklaşımı, topraklarında bulunan doğal kaynakları kiraya vererek gelir elde eden ve neredeyse hiç endüstriyel üretim yapmayan, nüfusunun çok küçük bir bölümünün üretim sürecine katıldığı ülkeleri betimlemektedir. Bu ülkelerdeki ekonomik işleyiş tamamıyla rant gelirine dayalıdır ve elde edilen gelirin önemli bir bölümü devlet tarafından çeşitli sübvansiyonlar eliyle halka dağıtılır. Devlet, aynı zamanda en büyük işverendir ve halk vergi vermez. Vergi vermeyen, devletin dağıttığı rant gelirine dayalı bir yaşam sürdüren ve devlet işinde çalışan halk ise siyasete olan ilgisini yitirir ve iktidarı sorgulamaktan kaçınan, edilgen bir görünüme bürünür. İktidar da rant gelirinin önemli bir bölümünü güvenliğe ayırarak, ekonomi politikaları ve rantın dağıtımı üzerinden iş çevrelerini kendisine eklemleyerek ve potansiyel muhalifleri sindirerek kendi devamlılığını güvenceye alan otoriter bir anlayışa yaslanır.

Kürdistan Bölgesi'ni değerlendirdiğimizde görmekteyiz ki, bu bölgede rantçı bir devlet yapısı kurgulanmaktadır. Nitekim Kürdistan Bölgesi’nde endüstriyel bir üretim yok denecek kadar azdır. Bunun yanı sıra, bölge ekonomisi neredeyse tamamen petrol ve doğalgaz satışından elde edilen gelire bağımlıdır. Kürdistan Bölgesi’nde en önemli işveren rantçı devlet yaklaşımının da altını çizdiği üzere bölgesel yönetimdir. Nitekim devlet bürokrasisi ve özellikle Peşmerge kadroları 2005 sonrası dönemde kabarık bir hal almıştır. Toplum yaşamında önemli bir rol oynayan büyük ve etkin aşiretlere yönetimde önemli pozisyonlar vermenin yanı sıra, bu aşiretlerin temsilcileri devlet bürokrasisinde ve Peşmerge kadrolarında ciddi görevlere atanmakta ve elde edilen rant gelirinin bir bölümü bu aşiretlere aktarılmaktadır. Çoğu rantçı devlette olduğu gibi, Kürdistan Bölgesi’nde de rant gelirinin dağıtımı hususunda adaletsizlik bulunmaktadır. Öyle ki, kişi başına düşen gelirin 6-7 bin doları bulduğu ifade edilen bölgede, nüfusun çok büyük bir bölümü bu rakamın çok altında bir yıllık gelire sahiptir. Sembolik bazı ödemeler dışında vergi vermeyen, elektrik, su gibi temel ihtiyaçlar noktasında sübvansiyonlardan yararlanan ve halkın genel itibarıyla iktidarı sorgulamaktan kaçındığı, otoriter bir siyasal yapıya sahip olan Kürdistan Bölgesi tipik bir rantçı devlet görüntüsü vermektedir.

Kürt ulusçuluğuna ve elde edeceği rant gelirine yaslanarak ve Irak'ın yaşadığı toplumsal/siyasal sorunları da destekleyici bir faktör olarak kullanarak bağımsızlık yönünde bir söylem benimseyen Kürdistan Bölgesi, henüz bu yönde yeterince destek alabilmiş değildir. Ancak orta/uzun vadede Kürdistan Bölgesi'nde bağımsız devlet oluşacaksa, bu devletin rantçı devlet yaklaşımının öngördügü bir yönetimsel/toplumsal görünüme sahip olacağı söylenebilir. 


\section{Kaynakça}

"An Interview With Dr. Mohamed Ali, Researcher at a Research Center Affiliated to Goran Movement and Faculty Member at University of Sulaymaniyah", ORSAM Guest, 21 Eylül 2013, http:/ /www.orsam.org.tr/ en/showOrsamGuest.aspx? ID=461, (Erişim Tarihi 22 Kasım 2014).

“Analiz: Türkiye’ye Akan Kuzey Irak Petrolü Kimi Neden Rahatsız Ediyor?”, Enerji Enstitüsü, 9 Haziran 2014, http://enerjienstitusu.com/2014/06/09/analiz-turkiyeye-akan-kuzey-irak-petrolu-kimi-neden-rahatsizediyor, (Erişim Tarihi 21 Kasım 2014).

"Ashti Hawrami Talks About 45 Million Barrels of Oil Reserves in Iraqi Kurdistan", Ekurd Daily, 11 Temmuz 2013, http://ekurd.net/mismas/articles/misc2013/7/state7208.htm, (Erişim Tarihi 23 Aralık 2014).

"Bağdat ve Erbil Arasında Petrol Anlaşması”, BBC Türkçe, 2 Aralık 2014, http://www.bbc.co.uk/turkce/ haberler/2014/12/141202_irak_petrol_anlasma, (Erişim Tarihi 20 Aralık 2014).

“BM: Suriyeli Kürtler Kuzey Irak’a Göç Ediyor”, BBC Türkçe, 18 Ağustos 2013, http://www.bbc.co.uk/turkce/ haberler/2013/08/130818_unhcr_suriye_irak, (Erişim Tarihi 8 Nisan 2015).

"Habur'a Ek 4 Yeni Sınır Kapısı", Rudaw, 24 Eylül 2014, http://rudaw.net/turkish/business/240920141, (Erişim Tarihi 1 Aralık 2014).

"Irak Anayasas1", ORSAM, http://www.orsam.org.tr/tr/trUploads/Yazilar/Dosyalar/20101224_irakanayasasi. pdf, (Erişim Tarihi 2 Ocak 2015).

“Irak Kürdistan Bölgesel Yönetimi’nde Siyasal Gelişmeler ve Türkiye ile Iraklı Kürtler Arasındaki İlişkilerin Geleceği”, ORSAM Tutanakları, No. 33, Eylül 2013.

"Irak Ordusundan Ayrılan Kürt Askerler, Peşmerge Ordusuna Alınıyor", Zaman, 22 Temmuz 2014, http:// www.zaman.com.tr/dunya_irak-ordusundan-ayrilan-kurt-askerler-pesmerge-ordusuna-aliniyor_2232951. html, (Erişim Tarihi 6 Aralık 2014).

"Irak Pazarı için Kentlerin İşbirliği Şart", Refleks, 7 Eylül 2013, http://www.refleksgazetesi.com/mansetdevam. asp?id=2251, (Erişim Tarihi 22 Kasım 2014).

“Irak’ta Yeni Kürt Hükümeti Seçimden 10 Ay Sonra Kuruldu”, Bugün, 18 Haziran 2014, http://www.bugun. com.tr/dunya/yeni-hukumet-10-ay-sonra-goreve-basladi-haberi/1150376, (Erişim Tarihi 8 Nisan 2015).

"Iraq Energy Outlook", IEA, Kasım 2012, http://www.iea.org/publications/freepublications/publication/ WEO_2012_Iraq_Energy_Outlook-1.pdf, (Erişim Tarihi 23 Nisan 2014).

“Iraqi Constitution", http://www.iraqinationality.gov.iq/attach/iraqi_constitution.pdf (Erişim Tarihi 29 Aralık 2014).

"Iraqi Kurdistan: Growing Effort to Silence Media", Human Rights Watch (HRW), 24 Mayis 2011, http://www. hrw.org/news/2011/05/24/iraqi-kurdistan-growing-effort-silence-media, (Erişim Tarihi 11 Kasım 2014).

“Kerkük Neden Önemli?”, Al Jazeera, 24 Haziran 2014, http://www.aljazeera.com.tr/haber/kerkuk-nedenonemli, (Erişim tarihi 20 Kasım 2014).

"Kuzey Irak Seçimlerinde Barzani Çıktı, Sürprizi Goran Yaptı", T24, 23 Eylül 2013, http://t24.com.tr/haber/ irak-kurt-bolgesi-secimlerinde-barzani-onde,240282, (Erişim Tarihi 22 Kasım 2014).

“Kuzey Irak’ta TPIC Bir Yatırım”, Hürriyet, 16 Mayıs 2013, http://www.hurriyet.com.tr/ekonomi/23293510. asp, (Erişim Tarihi 22 Aralık 2014).

"Kürt Petrol Projesi, Türk Şirketleri Zora Sokar”, BBC Türkçe, 14 Kasım 2012, http://www.bbc.co.uk/turkce/ haberler/2012/11/121114_turkey_iraq_shahristani_kurdish_oil.shtml, (Erişim Tarihi 20 Kasım 2014).

"Lack of Authority in Northern Iraq Increases Arm Smuggling”, Today's Zaman, 16 Ağustos 2004, http://www. todayszaman.com/national_lack-of-authority-in-n-iraq-increases-arm-smuggling_11483.html (Erişim Tarihi 28 Aralık 2014).

"List of Oil Companies in Kurdistan", Iraq Business News, 25 Haziran 2013, http://www.iraq-businessnews. com/2013/06/25/list-of-oil-companies-in-kurdistan, (Erişim Tarihi 1 Kasım 2014). 
"Local Authorities Aim to Expand Border Crossings With Iran Due to Trade Increase”, Rudaw, 6 Mayis 2014, http://rudaw.net/english/business/06052014, (Erişim Tarihi 1 Aralık 2014).

“Massoud Barzani: ISIS Fight Trumps Independence For Now”, Rudaw, 13 Ekim 2014, http://rudaw.net/ english/kurdistan/131020141 (Erişim Tarihi 29 Kasım 2014).

"Members of the Kurdistan Parliament", The Kurdistan Parliament, http://www.krg.org/p/p. aspx?l=12\&p=229\#elections_parliament (Erişim Tarihi 1 Ocak 2015).

“Overview: Kurdistan Region of Iraq, Education”, Invest Group, http://www.investingroup.org/publications/ kurdistan/overview/education, (Erişim Tarihi 18 Kasım 2014).

“PKK’lılar Peşmerge Oldu”, Hürriyet, 18 Temmuz 2007, http://www.hurriyet.com.tr/gundem/6914797.asp, (Erişim Tarihi 21 Aralık 2014).

“PKK’nın Eski Komutanından Peşmergeye Eğitim”, Sabah, 20 Kasım 2014, http://www.sabah.com.tr/ gundem/2014/11/20/pkknin-eski-komutanindan-pesmergeye-egitim, (Erişim Tarihi 26 Kasım 2014).

“Prime Minister Barzani’s Speech in the Reichstag Building”, Kurdistan Regional Government, 21 Mart 2013, http://www.krg.org/a/d.aspx?s=010000\&l=12\&a=47001, (Erişim Tarihi 22 Kasım 2014).

“Resolution 688”, http://daccess-dds-ny.un.org/doc/RESOLUTION/GEN/NR0/596/24/IMG/NR059624. pdf?OpenElement (Erişim Tarihi 28 Aralık 2014).

“The Kurdistan Parliament” Kurdistan Regional Government, http://www.krg.org/p/p.aspx?l=12\&s=030000\&r $=319 \& \mathrm{p}=229$ \#structure_parliament (Erişim Tarihi 31 Aralık 2014).

“Unemployment Increases in Kurdistan Region”, Iraq Business News, 12 Eylül 2014, http://www.iraqbusinessnews.com/tag/unemployment, (Erişim Tarihi 22 Kasım 2014).

“US to Take Airport in Iraq’s Kurdistan As Military Base: Officials”, Press TV, 23 Ekim 2014, http: //www.presstv. $\mathrm{ir} /$ detail/2014/10/23/383335/us-to-take-iraq-airport-as-military-base, (Erişim Tarihi 26 Ekim 2014).

“War in Iraq: What's Next For the Kurds?”, International Crisis Group, No. 10, Mart 2003.

Aegleton Jr., William, Mehabad Kürt Cumhuriyeti 1946, Emin Bozarslan (Çev.), İstanbul, Koral Yayınları, 1976.

Al Beblawi, Hazem, “The Rentier State in the Arab World”, The Arab State, Giacomo Luciani (der.), London, Routledge Publishing, 1990.

Aydın, Aydın, “Hereditary Oil Monarchies: Why Arab Spring Fails in GCC Arabian States?”, SDÜ Fen Edebiyat Fakültesi Sosyal Bilimler Dergisi, No. 30, Aralık 2013, s. 123-138.

Ayhan, Veysel, Barzani, Aziz ve Demir, Hakan, “Enerji Siyaseti, Türkiye-Irak Kürdistan Bölgesel Yönetimi: Boru Hatları, Petrol Satışı ve Bağdat'ın Pozisyonu”, IMPR Rapor, Kasım 2013.

Barkey, Henri J., "Kurdish Independence: One Day, But Certainly Not Now”, The American Interest, 8 Ağustos 2014, http://www.the-american-interest.com/2014/08/08/kurdish-independence-one-day-butcertainly-not-now (Erişim Tarihi 28 Kasım 2014).

Barkey, Henri J., “Turkey’s New Engagement in Iraq: Embracing Iraqi Kurdistan”, USIP Special Report, No. 237, Mayıs 2010.

Basedau, Matthias, "Resource Curse or Rentier Peace? The Ambigous Effects of Oil Wealth and Oil Dependence on Violent Conflict”, Journal of Peace Research, Cilt 46, No. 6, 2009, s. 757-776.

Baykal, Zana, "2014 Kürdistan Bölgesi Vilayet Seçimleri”, ORMER Perspektif Serileri, No. 2, Haziran 2014.

Beblawi, Hazem ve Luciani, Giacomo, The Rentier State: Nation, State and Integration in the Arab World, London, Croom Helm ve Istituto Affari Internazionali, 1987.

Bilgen, Onur, “Petrol ve Suudi Arabistan: Bir Lütuf Mu, Yoksa Bela Mı?”, Akademik Ortadoğu, Cilt 5, No. 1, 2010, s. $25-42$.

Bonfield, Craig, “Turkish-Kurdish Energy Cooperation in the Iraqi Conundrum”, CSIS, 19 Haziran 2014, http://csis.org/files/publication/140619_Kurdish.pdf, (Erişim Tarihi 22 Kasım 2014). 
Chaudhry, Kiren Aziz, "Economic Liberalization and the Lineages of the Rentier State", Comparative Politics, Cilt 27, No. 1, 1994, s. 1-25.

Cooper, Helen ve Gordon, Michael R., "Iraqi Kurds Expand Autonomy as ISIS Reorders the Landscape", The New York Times, 29 Ağustos 2014, http://www.nytimes.com/2014/08/30/world/middleeast/iraqi-kurdsexpand-autonomy-as-isis-reorders-the-landscape.html?_r=0 (Erişim Tarihi 30 Kasım 2014).

Cordesman, Anthony H. ve Khazai, Sam, Iraq in Crisis, Washington, Rowman\&Littlefield Publishing, 2014.

Crystal, Jill, "Coalitions in Oil Monarchies: Kuwait and Qatar", Comparative Politics, Cilt 21, No. 4, 1989, s. 427-443.

Delacroix, Jacques, "The Distributive State in the World System", Studies in Comparative International Development, Cilt 15, No. 3, 1980, s. 3-21.

Demir, Hakan, "Irak'ta Petrol Mücadelesi: Çok Uluslu Şirketler, Uluslararası Anlaşmalar ve Anayasal Tartışmaların Işığında Bir Analiz”, ORSAM Rapor, No. 103, Ocak 2012.

Demircioğlu, Fatih, “Amerikan İşgali Sonrası Kuzey Irak'ta Demokratikleşme Bağlamında Goran Hareketi”, Dicle Üniversitesi İktisadi ve İdari Bilimler Fakültesi Dergisi, Cilt 4, No. 7, 2014, s. $49-59$.

Duman, Bilgay, “Irak Bölgesel Kürt Yönetimi Parlamento Seçimleri ve Hükümet Senaryoları”, ORSAM, 25 Eylül 2013, http://www.orsam.org.tr/tr/yazilar_Yazdir.aspx?ID=4728 (Erişim Tarihi 1 Ocak 2015).

Duman, Bilgay, “Irak Kürt Bölgesinde Yasemin Kokusu”, Ortadoğu Analiz, Cilt 3, No. 27, 2011, s. 38-44.

Ekinci, Burhan, "Devlet Olmayan Devlet”, Al Jazeera Turk Dergi, 15 Ekim 2014, http://dergi.aljazeera.com. tr/2014/10/15/devlet-olmayan-devlet-kurdistan, (Erişim Tarihi 18 Kasım 2014).

Erkmen, Serhat ve Orhan, Oytun, “Kuzey Irak’ın Toplumsal, Siyasal Yapısı ve Kürt Bölgesel Yönetimi’nin Türkiye İle İlişkileri”, ORSAM Rapor, No. 40, 2011.

Erkmen, Serhat, "Key Factors For Understanding Political Dynamics in Northern Iraq: A Study of Change in the Region”, Uluslararası Hukuk ve Politika, Cilt 8, No. 31, 2012, s. 83-102.

Fine, Ben, “On Marx's Theory of Agricultural Rent", Economy and Society, Cilt 8, No. 3, 1979, s. 241-278.

Frankel, Jeffrey, “The Natural Resource Curse: A Survey”, Harvard Environmental Economics Program, Discussion Paper No. 21, 2010.

Freij, Hanna Yousif, "Alliance Patterns of a Secessionist Movement: the Kurdish Nationalist Movement in Iraq", Journal of Muslim Minority Affairs, Cilt 18, No. 1, 2007, s. 19-37.

Ghaffar, Mahmood, "Clientalism Within the Arabian Gulf States and Beyond", Central European Journal of International and Security Studies, No. 1, 2014, s. 30-51.

Gökler, Firuze Yağmur, “IŞi̇D Operasyonları Sonrası Irak’ta İnsani Durum, Türkmenler ve Türkiye’nin Irak’a Yaptığı İnsani Yardımlar”, ORSAM Bölgesel Gelişmeler Değerlendirmesi, No. 13, Ekim 2014.

Gray, Matthew, "A Theory of Late Rentierism in the Arab States of the Gulf", Center For International and Regional Studies Occasional Paper, No. 7, 2011.

Güleç, Derya Eğrican, “Gümrük Duvarı Örülmeden Kuzey Irak’a Yatırım Yapın”, Dünya, 31 Ocak 2013, http:// www.dunya.com/gumruk-duvari-orulmeden-kuzey-iraka-yatirim-yapin-180037h.htm, (Erişim Tarihi 22 Kasim 2014).

Hamid, Triska, "Corruption and Cronyism Hinder Kurdistan", Financial Times, 5 Eylül 2012, http://www. ft.com/intl/cms/s/0/ea716668-f759-11e1-8c9d-00144feabdc0.html\#axzz3O9F9zuFR, (Erişim Tarihi 17 Kasim 2014).

Hanish, Shak Bernard, "The Current Kurdish Iraqi Governments Relations: An Evaluation”, Journal of International Relations and Foreign Policy, Cilt 1, No. 2, Aralık 2013, s. 1-9.

Hardi, Nassous, "Maliki, Barzani Gain From Confrontation”, AlMonitor, 20 Aralı 2012, http:/ /www.al-monitor. com/pulse/ar/politics/2012/12/maliki-barzani-exploit-political.html (Erişim Tarihi 31 Aralık 2014).

Harding, Luke ve Hawramy, Fazel, "Kurds Hope Oil Boom Will Fuel Prosperous Independent Future", The Guardian, 14 Haziran 2014, http://www.theguardian.com/world/2014/jul/14/kurdish-technocratsdiscuss-kurdistan-oil-wealth, (Erişim Tarihi 27 Aralık 2014). 
Herb, Michael, "A Nation of Bureaucrats: Political Participation and Economic Diversification in Kuwait and the United Arab Emirates”, International Journal of Middle East Studies, Cilt 41, No. 3, 2009, s. 375-395.

Herb, Michael, "Does Rentierism Prevent Democracy?", Annual Meeting of the American Political Science Association (2002), 29 Ağustos-1 Eylül 2002, http://www2.gsu.edu/ polmfh/herb_2002_apsa.pdf, (Erişim Tarihi 14 Kasım 2014).

Hertog, Steffen, "Defying the Resource Curse: Explaining Successful State-Owned Enterprises in Rentier States”, World Politics, Cilt 62, No. 2, 2010, s. 261-301.

Hiltermann, Joost R., “The 1988 Anfal Campaign in Iraqi Kurdistan”, Online Encyclopedia of Mass Violence, Şubat 2008, http://faculty.washington.edu/goldberg/The-1988-Anfal-Campaign-in-Iraqi-Kurdistan.pdf (Erişim Tarihi 28 Aralık 2014).

Hür, Ayşe, “Osmanlı'dan Bugüne Kürtler ve Devlet: Kürt Milliyetçiliğinin Geç Doğumu”, SETA, http://arsiv. setav.org/ups/dosya/27464.pdf (Erişim Tarihi 28 Aralık 2014).

Jawad, Saad N., “The Iraqi Constitution: Structural Flaws and Political Implications”, LSE Middle East Centre Paper Series, No. 1, Kasım 2013.

Knights, Michael ve Ali, Ahmed, "Kirkuk in Transition: Confidence Building in Northern Iraq", The Washington Institute, Policy Focus No. 102, Nisan 2010.

Leezenberg, Michiel, "Iraqi Kurdistan: Contours of a Post Civil War Society”, Third World Quarterly, Cilt 26, No. 4-5, 2005, s. 631-647.

Luciani, Giacomo, “Allocation vs. Production States: A Theoretical Framework”, The Arab State, Giacomo Luciani (der.), London, Routledge Publishing, 1990.

Madi, Mohamed, “Haider al-Abadi: A New Era For Iraq?”, BBC News, 9 Eylül 2014, http://www.bbc.com/ news/world-middle-east-28748366, (Erişim Tarihi 22 Aralık 2014).

Mahdavy, Hossein, "Patterns and Problems of Economic Development in Rentier States: the Case of Iran", Studies in the Economic History of the Middle East: From the Rise of Islam to the Present Day, M.A. Cook (der.), Oxford, Oxford University Press, 1970, s. 428-467.

Makovsky, Alan, "Kurdish Agreement Signals New US Commitment”, The Washington Institute, Policywatch No. 341, Eylül 1998, http://www.washingtoninstitute.org/policy-analysis/view/kurdish-agreementsignals-new-u.s.-commitment (Erişim Tarihi 29 Aralık 2014).

Mills, Robin M., “Northern Iraq’s Oil Chessboard: Energy, Politics and Power”, Insight Turkey, Cilt 15, No. 1, 2013, s. 51-62.

Mirza, Ayad, “How to Start Up Doing Business in the Kurdistan Region?”, Deloitte Kurdistan Review, http:// www.investingroup.org/files/how\%20to\%20start-up\%20-\%20doing\%20business\%20in\%20kurdistan. pdf, (Erişim Tarihi 3 Ocak 2015).

Moore, Pete W., "Rentier Fiscal Crisis and Regime Stability: Business-State Relations in the Gulf”, Studies in Comparative International Development, Cilt 37, No. 1, 2002, s. 256-285.

Natali, Denise, "Kurdistan Seems to be Following Rentier State's Path”, The Kurdistan Tribune, Aralık 2013, http://kurdistantribune.com/2013/denise-natali-kurdistan-seems-be-following-rentier-states-path, (Erişim Tarihi 5 Ocak 2015).

Natali, Denise, Kurdish Quasi-State: Development and Dependency in Post Gulf-War Iraq, New York, Syracuse University Press, 2010.

Neurink, Judit, “The Gassing of Halabja Turned the Card on the Kurds in 1988”, Rudaw, 15 Mart 2014, http:// rudaw.net/english/kurdistan/150320141 (Erişim Tarihi 27 Aralık 2014).

Nuri, Ayub, “Why Kurdish Independence is the Only Solution For the World?”, Time, 16 Ağustos 2014, http:// time.com/3105066/kurdish-independence-iraq (Erişim Tarihi 29 Kasım 2014).

O’Leary, Brendan ve Bateman, David, “Article 140: Iraq's Constitution, Kirkuk and the Disputed Territories”, KNCNA, Mayıs 2008, http://www.kncna.org/docs/pdf_files/oleary_paper.pdf(Erişim Tarihi 29 Aralık 2014). 
Okruhlik, Gwenn, "Rentier Wealth, Unruly Law and the Rise of Opposition: The Political Economy of Oil States", Comparative Politics, Cilt 31, No. 3, 1999, s. 295-315.

Owen, E. Roger, "One Hundred Years of Middle Eastern Oil”, Brandeis University Crown Center for Middle East Studies, Middle East Brief, No. 24, Ocak 2008.

Park, Bill, Modern Turkey: People, State and a Foreign Policy in a Globalized World, Abingdon, Routledge Publishing, 2012.

Ricardo, David, Principles of Political Economy and Taxation, R.M.Hartwell (der.), London, Penguin Books, 1971.

Ross, Michael L., "Does Oil Hinder Democracy?”, World Politics, Cilt 53, No. 3, 2001, s. 325-361.

Ross, Michael L., "The Political Economy of the Resource Curse”, World Politics, Cilt 51, Ocak 1999, s. 297-322.

Sandbakken, Camilla, "The Limits to Democracy Posed By Oil Rentier States: The Cases of Algeria, Nigeria abd Libya”, Democratization, Cilt 13, No. 1, 2006, s. 135-152.

Schwarz, Rolf, "The Political Economy of State Formation in the Arab Middle East: Rentier States, Economic Reform and Democratization", Review of International Political Economy, Cilt 15, No. 4, 2008, s. 599-621.

Semin, Ali, “Irak'ta Derinleşen IŞİD Krizi ve Türkmenler”, BİLGESAM, 21 Ağustos 2014, http:/ /www.bilgesam. org/incele/1750/-irak\%E2\%80\%99ta-derinlesen-isid-krizi-ve-turkmenler/\#.VK0-KdKsWE0, （Erişim Tarihi 20 Aralık 2014).

Semin, Ali, “Kuzay Irak’ta Goran Hareketi ve KDP-KYB İle Denge Arayışları”, BİLGESAM, 19 Haziran 2014, http://www.bilgesam.org/incele/1620/-kuzey-irak--8217-ta-goran-hareketi-ve-kdp-kyb-ile-dengearayislari/\#.VKWDCdKsURE, (Erişim Tarihi 1 Ocak 2015).

Semin, Ali, “Türkiye’nin Irak Politikası Işı̆̆ında Kuzey Irak Açılımı”, Bilge Strateji, Cilt 3, No. 5, 2011, s. 179-205.

Sevim, Tuğçe Varol, "Rethinking Past, Today and Future of Kirkuk and its Black Gold", European Journal of Research on Education, Uluslararası İlişkiler Özel Sayısı, 2014, s. 12-16.

Shambayati, Hootan, "The Rentier State, Interest Groups and the Paradox of Autonomy: State and Business in Turkey and Iran", Comparative Politics, Cilt 26, No. 3, 1994, s. 308-309.

Sirkeci, İbrahim, "Turkmen in Iraq and Their Flight: A Demographic Question”, ORSAM Report, No. 21, Ocak 2011.

Söylemez, Haşim, "Kürdistan Sarhoşluğundan Geçim Derdine Kuzey Irak", Aksiyon, Kasım 2007, http://www. aksiyon.com.tr/aksiyon/newsDetail_openPrintPage.action?newsId=16672, (Erişim Tarihi 21 Kasım 2014).

Sözen, İlyas, Uslu, Kamil ve Öngel, Volkan, “Ortadoğu ve Kuzey Afrika Ülkelerinin Rantiyeci Ekonomi Yapıları”, İstanbul Ticaret Üniversitesi Sosyal Bilimler Dergisi, Cilt 10, No. 19, 2011, s. 89-107.

Sune, Engin, "Defining the Different: A Critical Analysis of the Rentier, Failed and Rogue State Theories", Ortadoğu Teknik Üniversitesi Sosyal Bilimler Enstitüsü, Yayımlanmamış Yüksek Lisans Tezi, Ankara, Temmuz 2012.

Sune, Engin, Özdemir, Ali Murat, “Rantçı Devlet Yazını Üzerine Deneme”, Uluslararası İlişkiler, Cilt 9, No. 35, 2012, s. 3-31.

Şahin, Hasan, “Irak Kürt Bölgesel Yönetimi ve Enerji”, Süreç Analiz, 22 Temmuz 2013, http://www.surecanaliz. org/makale/irak-kurt-bolgesel-yonetimi-ve-enerji, (Erişim Tarihi 2 Ocak 2015).

Tanchum, Michael, "Between Ankara and Tehran: How the Scramble for Kurdistan Can Reshape Regional Relations", Strategic Assessment, Cilt 17, No. 3, Ekim 2014, s. 67-80.

Ural, Selçuk, "Mütareke Döneminde İngiltere’nin Güneydoğu Anadolu Politikası”, Ankara Üniversitesi Türk İnkılap Tarihi Enstitüsü Atatürk Yolu Dergisi, No. 39, 2007, s. 425-463.

Üstün, Nazlı, “Türkiye-Kuzey Irak İlişkileri ve Ekonomik Yansımaları”, Konya Ticaret Odası (KTO) EtüdAraştırma Servisi, 2012.

Whitcomb, Alexander, “Kurdistan Region's Oil and Gas: Curse or Blessing?", Rudaw, 27 Nisan 2014, http:// rudaw.net/english/business/27042014, (Erişim Tarihi 6 Ocak 2015). 
Yeşilyurt, Nuri, “Ortadoğu’da Rejim Güvenliği ve Küçük Devlet”, Ankara Üniversitesi Sosyal Bilimler Enstitüsü, Yayımlanmamış Doktora Tezi, Ankara, 2013.

Yıldırım, Zafer, “1932-1975 Dönemi Irak’nn Ulus Devlet Yapısını Sarsan İsyancı Bir Hareket Olarak Barzaniler ve Irak Kürdistan Demokrasi Partisi”, Akademik Ortadoğu, Cilt 1, No. 2, 2007, s. 161-205.

Zebari, Abdel Hamid, “Opposition in Iraqi Kurdistan Questions Population Figures”, Al Monitor, 26 Haziran 2013, http://www.al-monitor.com/pulse/originals/2013/06/kurdistan-region-abnormal-populationgrowth.html (Erişim Tarihi 30 Kasım 2014). 